\title{
Synthesis and Characterization of First Row Transition Metal $p$-Toluenesulfonate Complexes and Chains
} \author{
Yuan-Zhu Zhang ${ }^{a}$, and Stephen M. Holmes ${ }^{a, b *}$ \\ ${ }^{a}$ Department of Chemistry and Biochemistry, University of Missouri-St. Louis, St. Louis, MO 63121, USA \\ ${ }^{b}$ Center for Nanoscience, University of Missouri-St. Louis, St. Louis, MO 63121, USA \\ ${ }^{c}$ Lutheran High School, South, St. Louis, MO 63123, USA \\ ${ }^{d}$ McCluer Senior High School, Florissant, MO 63031, USA
}

Philp J. Ferko ${ }^{a}$, Jeffrey R. Withers ${ }^{a}$, Hung Nguyen ${ }^{a}$, Charles Allison, ${ }^{a}$ Joshua Ema $^{c}$, Tim Ema ${ }^{d}$, Nigam P. Rath ${ }^{a, b}$,

\begin{abstract}
The preparation, structures, and spectroscopic properties of several molecular complexes and a one dimensional chain are described. Onedimensional $\left\{\text { trans }-\mathrm{Cr}^{\mathrm{II}}(\mathrm{DMF})_{2}(\mathrm{OTs})_{2}\right\}_{n}$ (1) chain and mononuclear complexes of trans- $\left[\mathrm{M}^{\mathrm{II}}(\mathrm{OTs})_{2}(\mathrm{DMF})_{4}\right]\left(\mathrm{M}^{\mathrm{II}}=\mathrm{Fe}, \mathbf{2} ; \mathrm{Co}, \mathbf{3}\right)$ and $\left[\mathrm{Ni}^{\mathrm{II}}(\mathrm{DMF})_{6}\right][\mathrm{OTs}]_{2}(4)$ stoichiometry are readily obtained from $\mathrm{DMF} / \mathrm{Et}_{2} \mathrm{O}$ solutions containing the parent anhydrous tosylate salts. A hydrated analogue, trans-[Fe $\left(\mathrm{Fe}^{\mathrm{II}}(\mathrm{OTs})_{2}\left(\mathrm{OH}_{2}\right)_{2}(\mathrm{DMF})_{2}\right](\mathbf{5})$, is obtained in minor quantities from solutions containing 2 . Electronic spectra indicate all of the complexes adopt octahedral geometries in dimethylformamide solution. Room temperature susceptibility data indicates that high spin electronic configurations are preferred for $\mathbf{1}(S=2), \mathbf{2}(S=2)$, and $\mathbf{3}(S=3 / 2)$ while $\mathbf{4}$ adopts an $S=1$ spin ground state. The solubility properties of the salts are also described.
\end{abstract}

Keywords: Cyanometalates; Crystal Structures; Magnetic Properties; Single-Molecule Magnets; Polynuclear Complexes

(C) 2016. This manuscript version is made available under the Elsevier user license 


\section{Introduction}

Binary complexes containing weakly-coordinating anions [19] are useful reagents for elaboration into more complex starting materials under a range of synthetic conditions [10-13]. Among these are the venerable perchlorate salts which are known for many alkali/alkaline earth [14-30], main group [14,15,31-36], early $[14,15,17,26,33,37-54]$ and late $[14,15,26,33,55-62]$ transition metal, and several lanthanide and actinide cations [14,15,54,63-66]. Unfortunately these highly soluble salts $[14,15,49-51,67-72]$ all are potentially explosive in the presence of organic ligands and solvents [7,14,15,40,69]. Consequently there has been continuing interest in developing synthetic methods that exploit other weakly-coordinating and nonoxidizing counteranions such as tetrafluoroborate [1,7,8,4951,72-79], hexafluorophosphate [7,8,49-51], hexafluorosilicate $[1,80-85]$, and tetra(aryl)borates $[1,9,86-90]$ to eliminate the inherent dangers associated with perchlorate use. However, while these anions are not considered as oxidants both $\mathrm{BF}_{4}^{-}$and $\mathrm{PF}_{6}{ }^{-}$have a propensity to undergo hydrolysis in aqueous media and generate corrosive HF solutions [1-9,91]. In contrast, tetra(aryl)borates can coordinate metal ions via $\pi$ bonding, are light-sensitive, and contain cleavable B-C bonds [1,86-89].

Despite their redox and hydrolytic stability the well-known sulfates [16,92-106] and Tutton's [16,100-122] salts are unsuitable for many transformations owing to their insolubility in most organic solvents [16,40,103]. In an effort to increase their general utility chemists naturally sought to modify the solubility of the dianionic sulfates via insertion of functional groups to afford monoanionic sulfonate derivatives. Examples include halo- [1,4,123-128], methane- [1,4-6,129-135], trifluoromethyl- [1,4-6,134-165], and various arylsulfonate [1,46,122,132,133,161-182] analogues. The higher solubility and rapid substitution kinetics are often exploited to afford clean reaction products and higher chemical yields [1,4,169,183-190].

There has been increasing interest in the use of binary transition metal trifluoromethanesulfonates ("triflates") and $p$ toluenesulfonates ("tosylates") as starting materials in inorganic syntheses owing to their high redox and hydrolytic stability under a range of chemical conditions [1,3-6,10-13,183-189]. The preparations of both salts generally involve: (1) acid addition to metal carbonates, hydroxides, or carboxylates or (2) treatment of metal halides with silver salts [4,135]. General procedures for their preparations from metal powders and aqueous acids were also recently reported $[5,6]$. Although the synthetic utility of triflates are well appreciated the corresponding tosylate analogues receive comparatively less attention in the chemical literature which may be related to their lower solubility than the corresponding triflates [4-6,171,174,178,186,190].

Hydrated tosylate salts are inexpensive to prepare, can be isolated in high crystalline yields, and are soluble in many polar solvents (e.g. methanol, water, and dimethylformamide) $[5,6,171,175,184,187]$. In an effort to increase their solubilities in a range of solvents we sought to replace coordinated aqua ligands for those that do not engage in intermolecular hydrogen bonding interactions. We reasoned that substitution for dimethylformamide (DMF) would encourage the formation of anhydrous molecular complexes with higher solubilities than the hydrates [156,185-187].

Structural reports describing sulfate and sulfonate derivatives are commonplace in the chemical literature. Among these are the Tutton [16,100-121], halosulfonates [123-128], methane- [129136], and arylsulfonate salts $[133,135,166-183]$. These generally adopt very complicated structures owing to extensive hydrogen bonding interactions between anions and water molecules present. In comparison the structures of binary transition metal $p$-toluenesulfonates are less explored and have been described for relatively few alkali [173,174], transition [122,133-135,175180,182,183,185-187], and lanthanide metal derivatives [169]. In an effort to better understand the coordination chemistry of tosylate anions and how donor ligands act to influence crystal packing in the solid state we chose to investigate a series of DMF solvates. We now describe the syntheses and X-ray structures of three mononuclear complexes and a one dimensional $p$-toluenesulfonate chain.

\section{Experimental}

\subsection{General Considerations}

All operations were conducted under an argon atmosphere using standard Schlenk and drybox techniques. Solution transfers utilized stainless steel cannulas. The preparation of anhydrous tosylate salts were previously described [5,6]. Solvents were distilled under dinitrogen from $\mathrm{Na} /$ benzophenone (diethyl ether) or dried over activated alumina ( $N, N^{\prime}$-dimethylformamide, DMF) and sparged with argon prior to use. Elemental analyses were performed by Robertson Microlit Laboratories.

\subsection{Preparation of Complexes}

\subsubsection{Synthesis of $\left\{\text { trans-Cr }{ }^{I I}(\mathrm{OTS})_{2}(\mathrm{DMF})_{2}\right\}_{n} \cdot n \mathrm{H}_{2} \mathrm{O}(\mathbf{1})$}

Solid $\mathrm{Cr}(\mathrm{OTs})_{2}(2.00 \mathrm{~g}, 5.07 \mathrm{mmol})$ was dissolved in DMF (10 $\mathrm{mL}$ ) with stirring and the pale blue-green solution was layered with $\mathrm{Et}_{2} \mathrm{O}(30 \mathrm{~mL})$. After 7 days the pale blue crystals were isolated via suction filtration, washed with $\mathrm{Et}_{2} \mathrm{O}(2 \times 5 \mathrm{~mL})$, and dried under vacuum for $2 \mathrm{~min}$. at room temperature. Yield: 1.68 g (59.4\%). Anal. Calcd for $\mathrm{C}_{20} \mathrm{H}_{30} \mathrm{~N}_{2} \mathrm{O}_{9} \mathrm{~S} 2 \mathrm{Cr}$ (1): C, 43.00; H, 5.42; N, 5.01. Found: C, 42.67; H, 5.22; N, 4.67. IR (Nujol, cm $\left.{ }^{1}\right): 3304(\mathrm{w}), 3148(\mathrm{w}), 1919(\mathrm{w}), 1655$ (vs), 1497 (s), 1419 (s), 1240 (vs), 1164 (vs), 1120 (vs), 1039 (vs), 1015 (vs), 950 (m), 819 (vs), 801 (s), 703 (vs), 685 (vs), 588 (s), 559 (vs), 420 (m). UV-vis (DMF): $\lambda_{\max } / \mathrm{nm}\left(\varepsilon_{\mathrm{M}} / M^{-1} \mathrm{~cm}^{-1}\right) 725 \mathrm{~nm}(19) . \mu_{\mathrm{eff}}\left(\mu_{\mathrm{B}}\right)=$ 5.02

\subsubsection{Synthesis of $\left\{\right.$ trans- $\left.\left[\mathrm{Fe}^{I I}(\mathrm{OTs})_{2}(\mathrm{DMF})_{4}\right]\right\} \cdot \mathrm{H}_{2} \mathrm{O}$ (2)}

Solid Fe(OTs) 2 (2.00 g, $5.02 \mathrm{mmol})$ was dissolved in DMF (10 $\mathrm{mL}$ ) with stirring and the pale green solution was layered with $\mathrm{Et}_{2} \mathrm{O}(30 \mathrm{~mL})$. After 7 days the white crystals were isolated via suction filtration, washed with $\mathrm{Et}_{2} \mathrm{O}(2 \times 5 \mathrm{~mL})$, and dried under vacuum for $2 \mathrm{~min}$. at room temperature. Yield: $1.44 \mathrm{~g}(40.4 \%)$. Anal. Calcd for $\mathrm{C}_{26} \mathrm{H}_{44} \mathrm{~N}_{4} \mathrm{O}_{11} \mathrm{~S}_{2} \mathrm{Fe}$ (2): C, 44.06; H, 5.91; N, 7.21. Found: C, 44.07; H, 6.26; N, 7.91. IR (Nujol, $\left.\mathrm{cm}^{-1}\right): 3291(\mathrm{~m}$, br), 3012 (m), 3000 (m), 2951 (vs), 2923 (vs), 2854 (vs), 1693 (m), 1648 (vs, br), 1616 (s, sh), 1600 (m, sh), 1497 (s), 1457 (s), 1440 (s), 1411 (s), 1376 (vs), 1285 (w), 1248 (vs), 1216 (s), 1169 (vs), 1119 (s), 1106 (s), 1097 (s), 1063 (m), 1047 (m), 1011 (vs), 865 (w), 854 (w), 825 (s), 815 (m), 799 (w), 714 (w), $682(\mathrm{~s}), 575(\mathrm{~m}), 567$ (s), 560 (s), 492 (w), 411 (m), 401 (m). $\mu_{\mathrm{eff}}\left(\mu_{\mathrm{B}}\right)=4.82$

\subsubsection{Synthesis of trans-[Co ${ }^{I I}\left(\mathrm{OTS}_{2}(\mathrm{DMF})_{4}\right](\mathbf{3})$}

Solid $\mathrm{Co}(\mathrm{OTs})_{2}(2.00 \mathrm{~g}, 4.98 \mathrm{mmol})$ was dissolved in DMF $(10 \mathrm{~mL})$ with stirring and the pink solution was layered with $\mathrm{Et}_{2} \mathrm{O}(30 \mathrm{~mL})$. After 7 days the pink/orange crystals were isolated via suction filtration, washed with $\mathrm{Et}_{2} \mathrm{O}(2 \times 5 \mathrm{~mL})$, and dried under vacuum for $2 \mathrm{~min}$. at room temperature. Yield: 1.77 g (51.2\%). Anal. Calcd for $\mathrm{C}_{26} \mathrm{H}_{42} \mathrm{~N}_{4} \mathrm{O}_{10} \mathrm{~S}_{2} \mathrm{Co}$ : C, 45.02; H, 6.10; 
N, 8.08. Found: C, 44.45; H, 5.70; N, 7.74. IR (Nujol, $\mathrm{cm}^{-1}$ ): 3013 (m), 3001 (s), 2952 (vs), 2923 (vs), 2867 (vs), 2854 (vs), 1693 (m), 1648 (vs, br), 1613 (s, sh), 1602 (s), 1497 (s), 1457 (s), 1439 (s), 1416 (s), 1411 (s), 1375 (vs), 1284 (w), 1245 (vs), 1228 (s), 1183 (s), 1169 (vs), 1120 (vs), 1107 (vs), 1096 (vs), 1063 (w), 1039 (s), 1011 (vs), 866 (vs), 854 (vs), 826 (s), 815 (m), $800(\mathrm{w}), 713(\mathrm{w}), 689$ (vs), 682 (vs), 576 (s), 656 (vs), 559 (vs), $414(\mathrm{~m}), 401(\mathrm{~m})$. UV-vis (DMF): $\lambda_{\max } / \mathrm{nm}\left(\varepsilon_{\mathrm{M}} / M^{-1} \mathrm{~cm}^{-1}\right)$ 479 (11), 497 (14), 527 (19). $\mu_{\text {eff }}\left(\mu_{\mathrm{B}}\right)=3.87$

\subsubsection{Synthesis of $\left[\mathrm{Ni}(\mathrm{DMF})_{4}\right][\mathrm{OTs}]_{2}(4)$}

Solid Ni(OTs) $)_{2}(2.00 \mathrm{~g}, 4.98 \mathrm{mmol})$ was dissolved in DMF (10 $\mathrm{mL})$ with stirring and the green solution was layered with $\mathrm{Et}_{2} \mathrm{O}$ (30 $\mathrm{mL})$. After 7 days the pale green crystals were isolated via suction filtration, washed with $\mathrm{Et}_{2} \mathrm{O}(2 \times 5 \mathrm{~mL})$, and dried under vacuum for $2 \mathrm{~min}$. at room temperature. Yield: $2.10 \mathrm{~g}(60.9 \%)$. Anal. Calcd for $\mathrm{C}_{26} \mathrm{H}_{42} \mathrm{~N}_{4} \mathrm{O}_{10} \mathrm{~S}_{2} \mathrm{Ni}(4)$ : C, 45.03; H, 6.10; N, 8.08. Found: C, 44.75; H, 6.06; N, 7.91. IR (Nujol, $\left.\mathrm{cm}^{-1}\right): 3143(\mathrm{~m})$, 3083 (m), 3062 (m), 3048 (m), 3015 (s), 3003 (s), 2955 (vs), 2924 (vs), 2867 (vs), 2855 (vs), 1690 (s, sh), 1653 (vs, br), 1611 (vs, sh), 1601 (s, sh), 1497 (vs), 1455 (vs), 1439 (vs), 1417 (s), 1410 (vs), 1402 (vs), 1372 (vs), 1283 (s), 1244 (vs), 1227 (vs), 1213 (vs), 1170 (vs), 1119 (vs), 1108 (vs), 1098 (vs), 1063 (s), 1048 (s), 1035 (vs), 1012 (vs), 868 (m), 855 (m), 849 (m), 825 (vs), 800 (s), 713 (s), 691 (vs), 681 (vs), 636 (w), 578 (s), 565 (vs), 558 (vs), $498(\mathrm{w})$. UV-vis (DMF): $\lambda_{\max } / \mathrm{nm}\left(\varepsilon_{\mathrm{M}} / M^{-1} \mathrm{~cm}^{-1}\right)$ 402 (11), 679 (4.2), 739 (4.3). $\mu_{\text {eff }}\left(\mu_{\mathrm{B}}\right)=2.71$

\subsection{IR and UV-vis Spectroscopies and Magnetic Measurements}

Infrared spectra were recorded as Nujol mulls between $\mathrm{KBr}$ plates on a Thermo-Fisher 6700 FTIR instrument in the 400$4000 \mathrm{~cm}^{-1}$ region. Electronic spectra were obtained on an Ocean Optics Flame-S-UV-VIS-ES spectrophotometer equipped with a DH-2000-BAL balanced deuterium tungsten source in the 200 to $850 \mathrm{~nm}$ range as DMF solutions. Magnetic susceptibility data was collected on a Johnson-Matthey susceptometer using solid $\mathrm{Hg}\left[\mathrm{Co}(\mathrm{NCS})_{4}\right]$ as a reference standard. Diamagnetic corrections were estimated using Pascal's constants [190].

\subsection{Structural Determinations and Refinements}

X-ray diffraction data for $\mathbf{1}$ and $\mathbf{3}$ were collected at 90.0(2) K on a Nonius kappaCCD diffractometer from irregular shaped crystals mounted in Paratone-N oil on glass fibers. Initial cell parameters were obtained (DENZO) [191] from ten $1^{\circ}$ frames and were refined via a least-squares scheme using all datacollection frames (SCALEPACK) [191]. Lorentz/polarization corrections were applied during data reduction. The structures were solved by direct methods (SHELXS97) [192] and completed by difference Fourier methods (SHELXL97) [192]. Refinement was performed against $F^{2}$ by weighted full-matrix least-squares (SHELXL97) [192], and empirical absorption corrections (either SCALEPACK [191] or SADABS [193]) were applied.

Single crystal structural data for $\mathbf{2 , 4}$, and $\mathbf{5}$ were collected at 100(2) $\mathrm{K}$ on a Bruker Apex-II CCD diffractometer using graphite-collimated MoK $\alpha$ radiation. All crystals were mounted in Paratone-N oil on glass fibers. The structures were solved by direct methods (SHELXS97) [192] and completed by difference Fourier methods (SHELXL97) [192]. Refinement was performed against $F^{2}$ by weighted full-matrix least-squares (SHELXL2013) [194] and empirical absorption corrections (SADABS) [193] were applied. The phenyl rings in 5 are disordered and were modelled with two partial occupancy rings at $50 \%$ each. The $\mathrm{C}^{-}-\mathrm{C} 3^{\prime}$ bond was refined with rigid bond constraint (DELU) while an EADP displacement parameter constraint was used for the C4-C3 one. Hydrogen atoms for 1-5 were found in difference maps and subsequently placed at calculated positions using suitable riding models with isotropic displacement parameters derived from their carrier atoms. Nonhydrogen atoms were refined with anisotropic displacement parameters. Atomic scattering factors were taken from the International Tables for Crystallography Vol. C. 82 [195]. All figures were generated using CrystalMaker® (CrystalMaker Software Ltd, www.crystalmaker.com).

\section{Results and discussion}

\subsection{Synthesis and spectroscopic characterization}

Under an inert atmosphere a series of six-coordinate divalent transition metal salts are easily prepared by aqueous digestion of finely divided metal powders with $p$-toluenesulfonic acid $[5,6]$. The crystalline hexaaquo salts readily crystalize from aqueous solution and their structures have been previously reported [6,133-138,172,175-180,182,183,185-187]. The salts are easily dehydrated under vacuum [5,6] and may be dissolved in dimethylformamide (DMF)/diethyl ether mixtures to form either a solvated chain, $\left\{\text { trans }-\mathrm{Cr}^{\mathrm{II}}(\mathrm{OTs})_{2}(\mathrm{DMF})_{2}\right\}_{n} \cdot n \mathrm{H}_{2} \mathrm{O}$ (1) or mononuclear complexes of trans- $\left[\mathrm{M}^{\mathrm{II}}(\mathrm{OTs})_{2}(\mathrm{DMF})_{4}\right] \cdot n \mathrm{H}_{2} \mathrm{O}(\mathrm{M}$ $=\mathrm{Fe}, \mathbf{2} ; n=1 ; \mathrm{Co}, \mathbf{3} ; n=0)$ and $\left[\mathrm{Ni}^{\mathrm{II}}(\mathrm{DMF})_{4}\right][\mathrm{OTs}]_{2}$ (4) stoichiometry. Small quantities of trans-[Fe $(\mathrm{OTs})_{2}\left(\mathrm{OH}_{2}\right)_{2}$ $\left.(\mathrm{DMF})_{2}\right](5)$ may also be crystallized in minor quantities from wet $\mathrm{DMF} / \mathrm{Et}_{2} \mathrm{O}$ mixtures of $\mathbf{2}$, but efforts to purposely prepare larger quantities of $\mathbf{5}$ have consistently met with failure. The complexes are highly soluble in $\mathrm{H}_{2} \mathrm{O}$, dimethylformamide, dimethylacetamide, methanol, and pyridine and lower solubility is found for tetrahydrofuran, ethyl acetate, ethanol, dimethyl sulfoxide, acetonitrile, and acetylacetone (Table 1); 4 displays the highest solubility of the series. Interestingly treatment of 1-4 with nitromethane, acetone, chloroform, and dichloromethane rapidly precipitates fine $\mathrm{M}(\mathrm{OTs})_{2}$ powders suggesting these may initially solubilize and rapidly eliminate coordinated DMF ligands. This behavior confirms that the DMF ligands are substitutionally labile under a variety of conditions [133,172,173,181-187,196,197].

The infrared spectra of $\mathbf{1 - 4}$ display strong absorptions consistent with the presence of $p$-toluenesulfonate anions and DMF chromophores. For 1 weak aromatic overtones (1919 and $1922 \mathrm{~cm}^{-1}$ ) are seen in its spectra while the other analogues do not display these absorptions [5,6,196,198]. Additional high intensity absorptions attributed to lattice water $v_{\mathrm{OH}}(\mathrm{ca} .3300 \mathrm{~cm}$ ${ }^{1}$ ) and DMF $v_{\mathrm{CO}}\left(\mathrm{ca} .1690 \mathrm{~cm}^{-1}\right.$ ) and $v_{\mathrm{CN}}$ stretches (ca. 1620 and $1497 \mathrm{~cm}^{-1}$ ) are also seen. Additional medium and weak intensity $v_{\mathrm{OH}}$ and $\delta_{\mathrm{HOH}}$ absorptions are also seen near ca. 3300 and 1650 $\mathrm{cm}^{-1}$ for 1 and 2 , respectively. These $\delta_{\mathrm{HOH}}$ scissor modes have similar energies and are comparable to those reported for a variety of $\left[\mathrm{M}^{\mathrm{II}}\left(\mathrm{OH}_{2}\right)_{6}\right][\mathrm{OTs}]_{2} \cdot n \mathrm{H}_{2} \mathrm{O}$ hydrates $[5,6,198]$. The tosylate antisymmetric $v_{\mathrm{a}}\left(\mathrm{SO}_{2}\right)$ and symmetric $v_{\mathrm{s}}\left(\mathrm{SO}_{2}\right)$ stretches are in the ranges seen for hexaaquo complexes and are found at ca. 1170 and between ca. $1119-1130 \mathrm{~cm}^{-1}$, respectively. The tosylate $\delta_{\mathrm{CS}}$ bands are between 559 and $569 \mathrm{~cm}^{-1}$ for 1-4 and are similar to those reported for the $\left[\mathrm{M}^{\mathrm{II}}\left(\mathrm{OH}_{2}\right)_{6}\right][\mathrm{OTs}]_{2}$ series, and are shifted by ca. $10 \mathrm{~cm}^{-1}$ to lower energies relative to anhydrous $\mathrm{M}^{\mathrm{II}}(\mathrm{OTs})_{2}$ salts [5,6,198]. Additional aromatic $\mathrm{CH}$ bending modes (e.g. out-of-plane $\mathrm{CH}$ wag, $\delta_{\mathrm{CH}}$ ) are found between 1040 
and $801 \mathrm{~cm}^{-1}$ verifying that aromatic tolyl rings are present in 14.

Electronic spectra collected as DMF solutions for 1-4 generally show absorptions that resemble those of octahedral aqua complexes [43,48,80-82,199-214]. The UV-vis spectrum of 1 shows a single broad absorption that is consistent with the presence of an octahedral high spin $\mathrm{Cr}^{\mathrm{II}}{ }_{\mathrm{HS}}(S=4)$ complex. The absorption is assigned to the spin-allowed ${ }^{5} T_{2 \mathrm{~g}} \leftarrow{ }^{5} E_{\mathrm{g}}$ transition $(725 \mathrm{~nm})$ while an additional and weaker intensity absorption $(428 \mathrm{~nm})$ is ascribed to small solution quantities of $\mathrm{Cr}^{\mathrm{III}}[43,80$ 83,203,204]. In comparison, the UV-vis spectrum of trans$\left\{\mathrm{Mn}^{\mathrm{II}}(\mathrm{DMF})_{2}(\mathrm{OTs})_{2}\right\}_{n} \quad(\mathbf{6})$ does not exhibit a discernable absorption owing to the spin- and Laporte-forbidden nature of optical transitions from the ${ }^{6} A_{1}$ ground state [196]. The data indicates that the chains fragment in solution and afford octahedral complexes.

For compound 2 a single spin-allowed ${ }^{5} E_{\mathrm{g}} \leftarrow{ }^{5} T_{2 \mathrm{~g}}$ electronic transition (ca. $1000 \mathrm{~nm}$ ) is expected for the $\mathrm{Fe}^{\mathrm{II}} \mathrm{HS}$ cations but the absorption lies outside the energy range investigated. Consistent with this assumption a small shoulder $(850 \mathrm{~nm})$ is seen in the optical spectrum of $\mathbf{2}$ [201,205,206]. Compound $\mathbf{3}$ displays electronic transitions that are typical of high spin octahedral $d^{7}$ complexes [186,199-206]. In six-coordinate Co ${ }_{\text {HS }}^{\text {II }}$ complexes the ${ }^{4} A_{2 g}$ ground state can participate in three light-induced excitations to afford higher energy quartet states $\left[{ }^{4} T_{2 \mathrm{~g}},{ }^{4} T_{1 \mathrm{~g}},{ }^{4} T_{1 \mathrm{~g}}\right]$, whose origins arise from lowering the symmetries of the ${ }^{4} F$ and ${ }^{4} P$ terms, respectively. For high spin $d^{7}\left[\mathrm{Co}^{\mathrm{II}}{ }_{\mathrm{HS}}\left(\mathrm{OH}_{2}\right)_{6}\right]^{2+}$ ions three optical transitions are expected, ${ }^{4} T_{2 \mathrm{~g}} \leftarrow{ }^{4} T_{1 \mathrm{~g}}(F) \quad\left(v_{1}, 1,235\right.$ $\mathrm{nm}),{ }^{4} A_{2 \mathrm{~g}} \leftarrow{ }^{4} T_{1 \mathrm{~g}}(F) \quad\left(v_{2}, 625 \mathrm{~nm}\right)$, and ${ }^{4} T_{1 \mathrm{~g}} \leftarrow{ }^{4} T_{1 \mathrm{~g}}(F)\left(v_{3}, 515\right.$ $\mathrm{nm})$, where spin-allowed transitions from the ${ }^{4} T_{1 \mathrm{~g}}(F)$ ground state leads to three spin-allowed transitions to ${ }^{4} T_{2 \mathrm{~g}},{ }^{4} A_{2 \mathrm{~g}}$, and ${ }^{4} P_{1}(P)$ excited states [200,201,204,206]. The lowest energy one $\left(v_{1}\right)$ occurs in the near-infrared and lies outside our experimental window $(350-850 \mathrm{~nm})$ [200-206]. The $v_{3}$ transition dominates the optical spectrum and lower energy shoulders (479 and 497 $\mathrm{nm})$ are found relative to the aqua complex $(515 \mathrm{~nm})[16,206]$. The shoulder origins are ascribed to either spin-orbit coupling, mixing of spin-forbidden transitions, or the presence of lower symmetry complexes in solution [201]. Likewise the intermediate energy absorption $(650 \mathrm{~nm})$ is also found at lower energy than the corresponding aqua complex possibly suggesting that DMF is a better donor ligands than water. Comparing the relative energies of optical transitions in three $\left[\mathrm{Co}_{\mathrm{HS}_{6}}^{\mathrm{II}} \mathrm{L}_{6}\right]^{2+}$ complexes, where $\mathrm{L}$ is an aqua, DMF, or DMSO ligands, we find that absorptions for DMSO solvates (1350, 684, $534 \mathrm{~nm}$ ) [206] are the lowest in the series, suggesting that DMF is an intermediate strength donor ligand. We note aqueous solutions of 3 and $\mathrm{Co}(\mathrm{OTs})_{2}$ give identical spectra and reports of complexes known to contain $\left[\mathrm{Co}^{\mathrm{II}}\left(\mathrm{OH}_{2}\right)_{6}\right]^{2+}$ cations, confirming that tosylates are easily displaced weakly coordinating anions [5,6,201-205].

Under the assumption 4 contains divalent nickel ions in an octahedral environment the electronic spectra are expected to exhibit three absorptions in the UV-visible (350-850 nm) range [201,203-211]. As is typically found for weak-field ligands the $v_{2}$ and $v_{3}$ transitions lead to a green appearance for many $\left[\mathrm{Ni}^{\mathrm{II}} \mathrm{L}_{6}\right]^{2+}$ complexes in solution. The absorption maxima may be used to estimate both $\Delta_{o}$ and $B$ in the frame of the spectrochemical series considering spin-allowed transitions for $d^{8}$ ions. For $\left[\mathrm{Ni}^{\mathrm{II}}\left(\mathrm{OH}_{2}\right)_{6}\right]^{2+}$ there are three electronic transitions: ${ }^{3} T_{2 \mathrm{~g}} \leftarrow{ }^{3} A_{2 \mathrm{~g}}\left(v_{1}, 1026 \mathrm{~nm}\right),{ }^{3} T_{1 \mathrm{~g}}\left({ }^{3} F\right),{ }^{1} E_{\mathrm{g}} \leftarrow{ }^{3} A_{2 \mathrm{~g}} \quad\left(v_{2}, 741 \mathrm{~nm}\right)$, and ${ }^{3} T_{1 \mathrm{~g}}\left({ }^{3} P\right) \leftarrow{ }^{3} A_{2 \mathrm{~g}}\left(v_{3}, 395 \mathrm{~nm}\right)$. The energy difference between the $A_{2 \mathrm{~g}}$ and $T_{2 \mathrm{~g}}$ states gives $\Delta_{\mathrm{o}}=1026 \mathrm{~nm}$ [199-211] and the unsymmetrical nature of the lowest energy band is generally ascribed as intensity stealing from the ${ }^{1} E_{\mathrm{g}} \leftarrow{ }^{3} A_{2 \mathrm{~g}}$ transition via configurational interactions with the ${ }^{3} T_{1 \mathrm{~g}}(\mathrm{~F})$ level. Unfortunately the lowest energy $\left(v_{1}\right)$ transition for $4+2 \mathrm{DMF}$ lies outside the experimental window and effectively prevents a direct estimation of $\Delta_{\mathrm{o}}[198,209]$. These absorptions arise from ${ }^{3} T_{1 \mathrm{~g}}(P)$ and split ${ }^{1} T_{1 \mathrm{~g}}(F)$ transitions from the ${ }^{3} A_{2 \mathrm{~g}}$ ground state [201]. Within the experimental range investigated $\left[\mathrm{Ni}^{\mathrm{II}}(\mathrm{DMF})_{6}\right]\left[\mathrm{ClO}_{4}\right]_{2}$ displays absorptions at 400, 691, and $735 \mathrm{~nm}$ and resembles data collected for 4 in DMF (402, 679, and $739 \mathrm{~nm}$ ) suggesting they adopt identical solution structures [206,209,211]. Likewise aqueous solutions of $\mathrm{Ni}(\mathrm{OTs})_{2}(393,659,721 \mathrm{~nm})$ and $\left[\mathrm{Ni}\left(\mathrm{OH}_{2}\right)_{6}\right][\mathrm{OTs}]_{2}$ display comparable spectra $[402,679$, and 739 $\mathrm{nm}$ ] confirming that the tosylates are outer-sphere anions. In comparison to other $\left[\mathrm{Ni}^{\mathrm{II}} \mathrm{L}_{6}\right]^{2+}$ complexes, where $\mathrm{L}$ is $\mathrm{MeOH}$ $(1186,703,400 \mathrm{~nm})$ and DMSO (1294, 700, 771, and $416 \mathrm{~nm})$, the highest energy optical transitions are seen for the weakest donor ligand [206,209,211,212], indicating that DMF is an intermediate strength donor as expected.

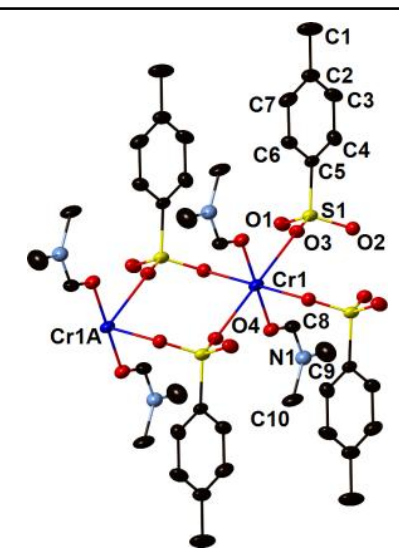

Fig. 1. X-ray structures of one-dimensional chains present approximately along the crystallographic $c$-direction in $\mathbf{1}-\mathrm{H}_{2} \mathrm{O}$. Hydrogen atoms are eliminated for clarity and ellipsoids are at the $50 \%$ level.

\subsection{Crystallographic studies}

Compound 1- $\mathrm{H}_{2} \mathrm{O}$ crystallizes as one-dimensional ribbons in the monoclinic $P 2_{1} / n$ space group [Table 2]. The chains bear a structural resemblance to those of $\left.\{\text { trans-M(L) })_{2}(\mathrm{OTs})_{2}\right\}_{n}$ stoichiometry, reported by Loiseleur and Holmes, respectively, where $\mathrm{M}=\mathrm{Cd}^{2+}$ and $\mathrm{Mn}^{\mathrm{II}}$ and $\mathrm{L}=\mathrm{OH}_{2}$ and DMF [6,191,213]. The chains are composed of embedded and corner shared cis$\left[\mathrm{Cr}_{2}{ }_{2}{ }_{2}\left(\mu-\mathrm{O}_{3} \mathrm{SC}_{6} \mathrm{H}_{4} \mathrm{Me}\right)_{4}(\mathrm{DMF})_{4}\right]$ squares, where alternate corners are occupied by chromium(II) and tosylate anions [Fig. 1]. The tosylate tolyl rings adopt anti-orientations with respect to the distorted $\left\{\mathrm{Cr}_{2} \mathrm{~S}_{2}\right\}$ squares and are in close proximity [ca. 5.224(2) $\AA$ ] to adjacent chains along the crystallographic $y$ direction, suggesting $\pi$-stacking interactions are operative $\mathbf{1}$ [Fig. $2]$.

In structures of $\mathbf{1}-\mathrm{H}_{2} \mathrm{O}$ the tolyl rings lie parallel to coordinated DMF ligands and terminal sulfoxide S-O units and bear structural features that are reminiscent of many $\left[\mathrm{M}^{\mathrm{II}}\left(\mathrm{OH}_{2}\right)_{6}\right][\mathrm{OTs}]_{2} \quad$ salts $\quad[6,133-138,175-180,182,183,185-$ 187,191,213]. The tosylate bonds in $\mathbf{1}-\mathrm{H}_{2} \mathrm{O}$ and \{trans$\left.\mathrm{Mn}(\mathrm{DMF})_{2}(\mathrm{OTs})_{2}\right\}_{n}$ (6) are remarkably similar with S1-C [1.773(3) and 1.767(2) $\AA]$ and average S1-O bonds [1.457(2) and $1.456(1) \AA]$ seen. Interestingly the $\mathrm{M}-\mathrm{O}_{\mathrm{OTs}}$ distances in $\left\{\text { trans }-\mathrm{Mn}(\mathrm{DMF})_{2}(\mathrm{OTs})_{2}\right\}_{n}$ are considerably longer [2.156(1) and 2.194(1) $\AA$ ] than those in $1-\mathrm{H}_{2} \mathrm{O}$ suggesting bonding predictions are more complicated than those using only simple electrostatic arguments [Table 3]. We note the $\mathrm{Cr} 1-\mathrm{O}$ distances 
in $1-\mathrm{H}_{2} \mathrm{O}$ are longer than those found in tosylate-bridged molecular $\left\{\mathrm{Cr}_{2}^{\mathrm{III}}(\mu \text {-OTs })_{6}(\mathrm{THF})_{4}\right\}$ squares [1.973(2) $\AA$ avg.] being entirely consistent with the presence of divalent chromium centers [215]. The $\mathrm{Cr} 1-\mathrm{O}$ distances in $\mathbf{1}-\mathrm{H}_{2} \mathrm{O}$ range between 2.038(2) and 2.403(2) $\AA$ [Cr1-O4 and Cr1-O3] suggesting JahnTeller distortions are operative [Table 3]. The elongated axes are oriented parallel to the crystallographic $a$-direction and resemble structures of $\left[\mathrm{Cr}^{\mathrm{II}}\left(\mathrm{OH}_{2}\right)_{6}\right][\mathrm{OTs}]$ [2.035(1) and 2.487(1) $\AA$ ] and $\left[\mathrm{NH}_{4}\right]_{2}\left[\mathrm{Cr}^{\mathrm{II}}\left(\mathrm{OH}_{2}\right)_{6}\right]\left[\mathrm{SO}_{4}\right]_{2}[2.052(1)$ to $2.327(1) \AA]$ where JahnTeller distortions were also seen [6]. This sharply contrasts those in $\left[\mathrm{Cr}^{\mathrm{II}}\left(\mathrm{OH}_{2}\right)_{6}\right]\left[\mathrm{SiF}_{6}\right],\left[\mathrm{Cr}^{\mathrm{II}}\left(\mathrm{OH}_{2}\right)_{4}\right]\left[\mathrm{SiF}_{6}\right]$,

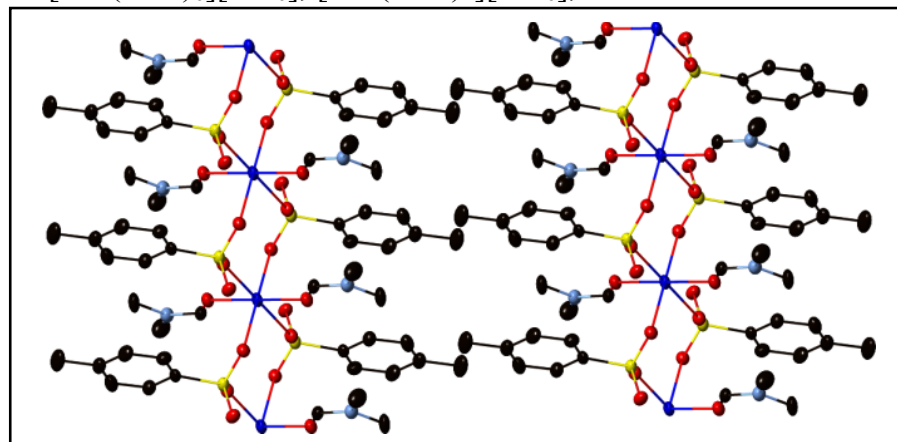

Fig. 2. Packing diagram for $\mathbf{1}-\mathrm{H}_{2} \mathrm{O}$ in the $b c$-plane. Hydrogen atoms are eliminated for clarity and thermal ellipsoids are at the $50 \%$ level .

and $\left[\mathrm{Cr}^{\mathrm{II}}\left(\mathrm{OH}_{2}\right)_{4}\right]\left[\mathrm{SO}_{4}\right] \cdot \mathrm{H}_{2} \mathrm{O}$ [2.106(2), 2.041(1), and 2.053(1) $\left.\AA\right]$, which display little variation in their $\mathrm{Cr}-\mathrm{O}$ bond lengths [80-82]. However, the latter two salts do have rather long $\mathrm{Cr} \cdots \mathrm{F}$ contacts [ca. 2.40(1) §] reflecting tetragonal elongation associated with Jahn-Teller distortions may indeed be present. The crystallographic data suggests that minimization or elimination of hydrogen bonding interactions in $\mathrm{CrO}_{6}$ coordination environments may encourage Jahn-Teller distortions to be seen $[6,80,82]$.

Compounds $\mathbf{2}-\mathrm{H}_{2} \mathrm{O}$ and $\mathbf{3}$ crystalize as neutral and tetragonally compressed mononuclear complexes in the monoclinic $P 2_{1} / n$ space group [Table 2]. The $C_{2^{-}}$symmetric trans-[M $\left[\mathrm{M}^{\mathrm{II}}(\mathrm{OTs})_{2^{-}}\right.$ $\left.(\mathrm{DMF})_{4}\right]$ complexes contain axial tosylate anions in addition to four coordinated DMF ligands that reside their equatorial planes. The $\mathrm{M}^{\mathrm{II}}-\mathrm{O}_{\text {DMF }}$ [2.237(7), Fe1-O1; 2.1574(7) $\AA$, Fe1-O2] bonds in $\mathbf{2}-\mathrm{H}_{2} \mathrm{O}$ are nearly equivalent, while those in $\mathbf{3}$ [2.231(2), Co1O1A; 2.049(1), , Co1-O1B] are markedly different, suggesting steric crowding or weak Jahn-Teller distortions may be present in the latter. The $\mathrm{M}^{\mathrm{II}}-\mathrm{O}_{\text {ОTs }}[2.0958(7)$ and 2.028(1) $\AA$ ] bonds appear to be shorter than the corresponding $\mathrm{M}^{\mathrm{II}}-\mathrm{O}_{\mathrm{DMF}}$ ones suggesting significant electrostatic interactions which scale with $\mathrm{M}^{\mathrm{I}}$ electronegativity are operative in $2-\mathrm{H}_{2} \mathrm{O}$ and 3 , respectively

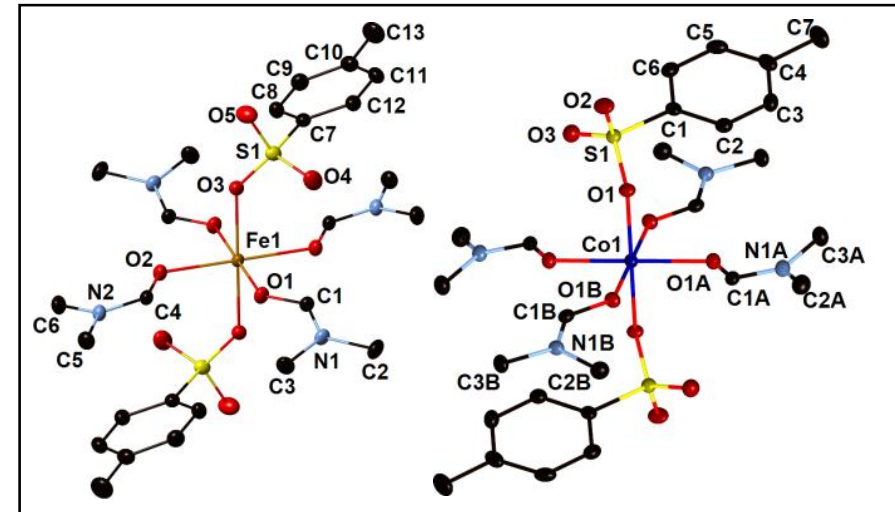

Fig. 3. X-ray structures of (left) $2-\mathrm{H}_{2} \mathrm{O}$ and (right) 3. Thermal ellipsoids are at the $50 \%$ level and all hydrogen atoms are removed for clarity.
[Table 3].

The $\mathrm{Fe}-\mathrm{O}$ and $\mathrm{Co}-\mathrm{O}$ bonds in $\mathbf{2}-\mathrm{H}_{2} \mathrm{O}$ and $\mathbf{3}$ are similar to those found in two dimensional grids of $\left[\mathrm{M}^{\mathrm{II}}(\mathrm{BDS})(\mathrm{NMP})_{3}\right]\left(\mathrm{M}^{\mathrm{II}}=\right.$ $\mathrm{Mn}, \mathrm{Fe}, \mathrm{Co}]$ stoichiometry, where $\mathrm{BSD}=1,4-$ benzenedisulfonate and NMP $=N$-methylpyrrolidone [216]. The structures are composed of two mer-[M $\left.\mathrm{M}^{\mathrm{II}}(\mathrm{NMP})_{3}\right]^{2+}$ fragments that share common and 4-connected BDS dianion to form cationic one dimensional chains, $\left\{\left[\mathrm{M}^{\mathrm{II}}(\mathrm{NMP})_{3}\right]_{2}(\mu-1,2-\right.$ $\left.\left.\mathrm{O}_{3} \mathrm{SC}_{6} \mathrm{H}_{4} \mathrm{SO}_{3}-\mu-1,2\right)\right\}_{n}{ }^{2+}$, that propagate along the crystallographic $a$-direction. The chains are linked by additional perpendicular bis( $\mu$-BDS) units along the $b$-direction to give a two dimensional grid of parallel ribbons [216]. The metal coordination spheres have rather long $\mathrm{Fe}-\mathrm{O}_{\mathrm{BDS}}[2.1396(5)$ to 2.1465(5) $\AA$ ] and Co-O $\mathrm{BDs}$ [2.0944(6) to 2.1023(6) $\mathrm{A}$ ] distances while the $\mathrm{Fe}-\mathrm{O}_{\mathrm{NMP}}$ and $\mathrm{Co}-\mathrm{O}_{\mathrm{NMP}}$ ones span a larger range [2.0927(5) to 2.1649(5) $\AA$ ] and [2.0453(6) to 2.1275(6) $\AA$ ]. In comparison to the Christoffers and Wickleder data the $\mathrm{M}-\mathrm{O}_{\mathrm{DMF}}$ distances are longer in $2-\mathrm{H}_{2} \mathrm{O}$ [2.237(7) and 2.1574(7) $\AA$ ] while the $\mathrm{Co}-\mathrm{O}_{\mathrm{DMF}}$ ones in $\mathbf{3}$ [Table 3] vary considerably [2.231(2) and 2.049(1) A] [216]. In another structurally characterized chain, $\left\{\text { trans }-\mathrm{Co}(\mathrm{BS})_{2}(\mathrm{EtOH})_{2}\right\}_{n}$, where BS is a benzenesulfonate anion the $\mathrm{Co}-\mathrm{O}_{\mathrm{BS}}\left[2.132(8)\right.$ and 2.108(7) $\AA$ ] and $\mathrm{Co}-\mathrm{O}_{\mathrm{EtOH}}$ bonds $[2.049(8) \AA]$ are slightly shorter than the $\mathrm{Co}-\mathrm{O}_{\text {Отs }}[2.231(2)$ and 2.049(1) $\AA]$ and Co1-O $\mathrm{O}_{\mathrm{DMF}}$ ones [2.028(1) $\AA$ ], consistent with ethanol being a weaker donor than DMF as expected. Intramolecular hydrogen bonding interactions between coordinated $\mathrm{EtOH}$ and benzenesulfonate ligands are also found
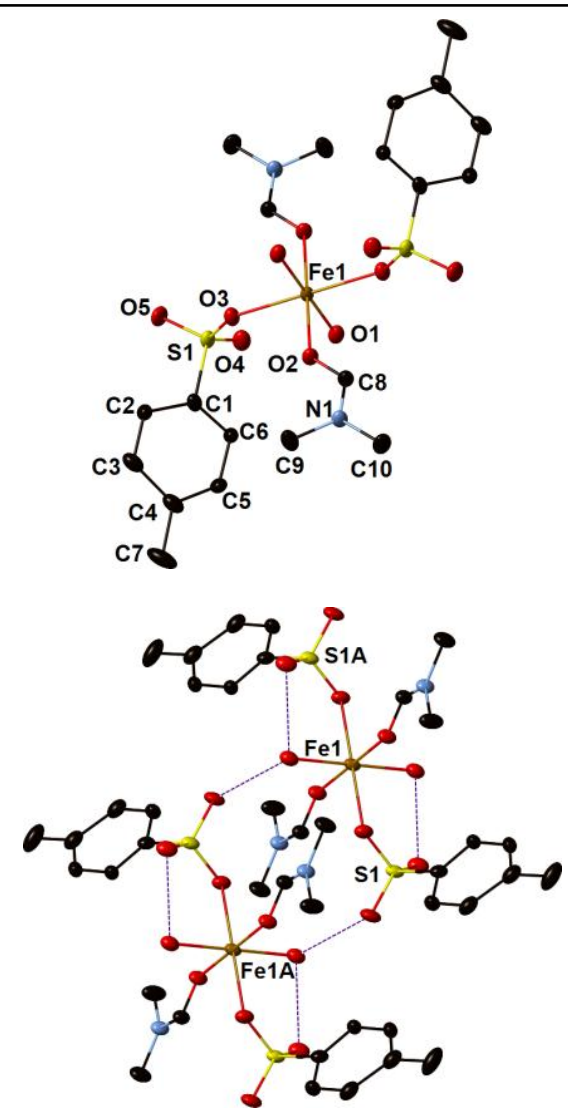

Fig. 4. (top) Molecular structure of 5. (bottom) X-ray structure of 5 highlighting intra- and intermolecular hydrogen bonding interactions (dotted lines). Hydrogen atoms are eliminated for clarity and ellipsoids are at the 50\%

and also probably contribute to shorter Co-O distances in their structure [217]. 
Compounds $2-\mathrm{H}_{2} \mathrm{O}$ and $\mathbf{3}$ also bear notable structural similarities to hexaaqua complexes described by Cotton. The M$\mathrm{O}$ bonds in $\mathbf{2}$ and $\mathbf{3}$ have average lengths that resemble those observed in $\left[\mathrm{NH}_{4}\right]_{2}\left[\mathrm{M}^{\mathrm{II}}\left(\mathrm{OH}_{2}\right)_{6}\right]\left[\mathrm{SO}_{4}\right]_{2}$ Tutton's and $\left[\mathrm{M}^{\mathrm{II}}\left(\mathrm{OH}_{2}\right)_{6}\right] \mathrm{SiF}_{6}$ salts [82]. Interestingly the $\mathrm{S} 1-\mathrm{O} 3$ and $\mathrm{S} 1-\mathrm{O} 1$ distances [1.4793(8) and 1.490(2) A] are the longest of the sulfonate $\mathrm{S}-\mathrm{O}$ bonds, suggesting that some charge localization may be operative within the tosylate anions of $2-\mathrm{H}_{2} \mathrm{O}$ and 3 [Table 3]. Further analysis shows that the O- $\mathrm{M}^{\mathrm{II}}-\mathrm{O}$ angles in 2$\mathrm{H}_{2} \mathrm{O}$ and 3 deviate significantly from ideal octahedral geometries further indicating steric interactions may lead to structural distortions. The $\left[\mathrm{M}^{\mathrm{II}}\left(\mathrm{OH}_{2}\right)_{6}\right]^{2+}$ cations have $\mathrm{O}-\mathrm{M}^{\mathrm{II}}-\mathrm{O}$ angles that range between $89.25(6)$ and $91.1(1)^{\circ}$ (for $\mathrm{Fe}^{\mathrm{II}}$ ) and 88.94(94(3) and $89.69(4)^{\circ}$ (for $\mathrm{Co}^{\text {II }}$ ) Tutton's salts, while the hexafluorosilicates are between 88.93(8) and 89.53(4) ${ }^{\circ}$ [82]. However in both complexes the $\mathrm{O}-\mathrm{M}^{\mathrm{II}}-\mathrm{O}$ angles range from slightly acute $\left[88.34(3), \mathrm{O} 1-\mathrm{Fe} 1-\mathrm{O} 2 ; 83.74(6)^{\circ}, \mathrm{O} 1-\mathrm{Co} 1-\mathrm{O} 1 \mathrm{~A}\right]$ to linear suggesting that steric congestion is more pronounced in the latter complex. This is entirely consistent with the presence of smaller cobalt(II) ions [Table 3].

The molecular tosylates $\left(\mathbf{2}-\mathrm{H}_{2} \mathrm{O}\right.$ and 5) may be considered as structural analogues of trans- $\left[\mathrm{Fe}\left(\mathrm{O}_{3} \mathrm{SR}\right)_{2}(\mathrm{py})_{4}\right]$ complexes originally described by Thompson, where $\mathrm{R}=\mathrm{CF}_{3}, \mathrm{Me}$, and $\mathrm{C}_{6} \mathrm{H}_{4} \mathrm{Me}[127,135,176]$. The tetragonally compressed trans$\left[\mathrm{Fe}^{\mathrm{II}}(\mathrm{OTs})_{2}(\mathrm{py})_{4}\right]$ complexes adopt idealized $D_{4 \mathrm{~h}}$ symmetric $\mathrm{FeO}_{2} \mathrm{~N}_{4}$ coordination environments, where the Fe- $\mathrm{N}_{\mathrm{py}}$ [2.221(3) and 2.245(3) $\AA$ ] and $\mathrm{Fe}-\mathrm{O}_{\mathrm{OTs}}[2.076(2) \AA]$ bonds are longer and slightly shorter than the corresponding $\mathrm{Fe} 1-\mathrm{O}_{\mathrm{DMF}}[2.1237(7)$ and 2.1574(7) $\AA$ ] and Fe1-O OTs [2.0958(7) $\AA$, Fe1-O3] ones in 2$\mathrm{H}_{2} \mathrm{O}$ [Table 3]. In structures of $2-\mathrm{H}_{2} \mathrm{O}$ the $\mathrm{M}-\mathrm{O}_{\mathrm{OTs}}$ bonds are longer than those seen for the entire trans- $\left[\mathrm{Fe}^{\mathrm{II}}\left(\mathrm{O}_{3} \mathrm{SR}\right)_{2}(\mathrm{py})_{4}\right]$ series $\left(\mathrm{R}=\mathrm{CF}_{3}, \mathrm{Me}, \mathrm{C}_{6} \mathrm{H}_{4} \mathrm{Me} ; 2.11,2.06\right.$, and $\left.2.08 \AA\right]$ suggesting DMF ligands are slightly better $\sigma$ donors than pyridine for oxophillic iron centers. Likewise the S-O distances are between $1.421(3)$ and $1.474(2) \AA$, with the shortest one corresponding to a terminal sulfoxide unit. In comparison, the S$\mathrm{O}$ bonds in $2-\mathrm{H}_{2} \mathrm{O}$ range between $1.4466(8)$ and 1.4793(8) $\AA$, with the coordinated tosylate oxygen [S1-O3] displaying the longest bond of the three.

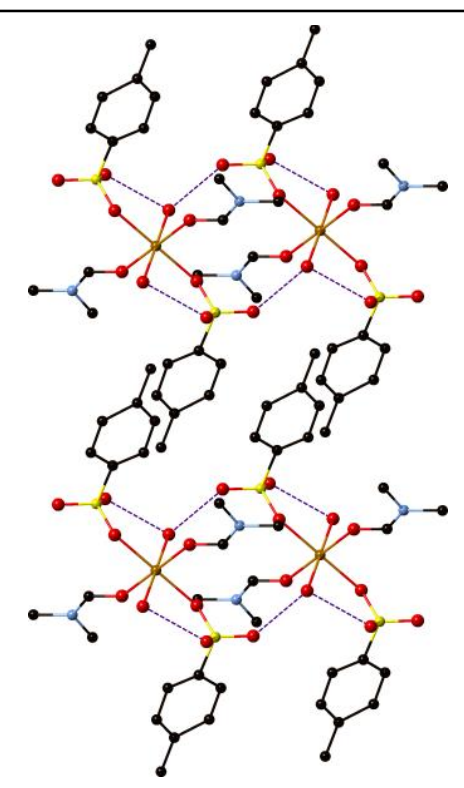

Fig. 5. Packing diagram for $\mathbf{5}$ viewed along the crystallographic $b$-direction. Intermolecular hydrogen bonding (dotted lines) are found between coordinated aqua and tosylate ligands along the crystallographic $a$-direction. Hydrogen atoms are eliminated, thermal ellipsoids are at the 50\% level, and only iron (orange), sulfur (yellow), oxygen (red), nitrogen (blue), and carbon (black) atoms are shown for clarity.
The corresponding Fe-O distances in $\mathbf{5}$ also display noticeable differences when compared to other iron sulfonate complexes [127,135,140]. Compound $\mathbf{5}$ crystallizes as a mononuclear complex in the triclinic $P-1$ space group [Table 2 and Fig. 4]. The tosylate bonds are related via rotation and give a $C_{2^{-}}$ symmetric complex of trans-[Fe $\left.\mathrm{FI}^{\mathrm{II}}(\mathrm{OTs})_{2}\left(\mathrm{OH}_{2}\right)_{4}\right]$ stoichiometry. The tosylate $\mathrm{Fe} 1-\mathrm{O} 3$ bonds [2.1428(8) $\AA$ ] are between the $\mathrm{Fe}$ $\mathrm{O}_{\text {aqua }}[2.1498(9) \AA, \mathrm{Fe} 1-\mathrm{O} 1]$ and $\mathrm{Fe}-\mathrm{O}_{\mathrm{DMF}}[2.0804(7) \AA]$ ones in 3 [Table 3] and are similar to the $\mathrm{Fe}-\mathrm{O}_{\text {sulfate }}$ distances seen for cis- $\left[\mathrm{Fe}^{\mathrm{II}}\left(\mu-\mathrm{OSO}_{3}\right)_{2}\left(\mathrm{OH}_{2}\right)_{4}\right]$ units [avg. 2.12(5) $\AA$ ] in structures of $\mathrm{FeSO}_{4} \cdot 4 \mathrm{H}_{2} \mathrm{O}$ [96]. Under the assumption coordinated aqua and DMF ligands are respectable $\sigma$ donors the Fe-O distances will be dependent on both donor strength and ligand size. Surprisingly, the smaller aqua ligands display rather long $\mathrm{Fe}-\mathrm{O}$ distances in comparison to the $\mathrm{Fe}-\mathrm{O}_{\mathrm{DMF}}$ ones, suggesting additional effects may be operative (vide infra). Upon further inspection both intra- and intermolecular hydrogen bonding contacts [ca. 2.687(3) $\AA$ ] are present linking coordinated aqua and tosylates along the crystallographic $b$-direction [Fig. 4 , right]. We propose these secondary interactions act to decrease aqua ligand basicity and concomitantly elongates their $\mathrm{Fe}-\mathrm{O}_{\text {aqua }}$ bonds. Consistent with this assumption the S1-O3 and S1-C7 bonds [1.4720(9) and $1.767(1) \AA]$ are also comparable to those in 2 , while the remaining S1-O ones are slightly longer, further indicating that hydrogen bonding is important in structures of 5 [Table 3].

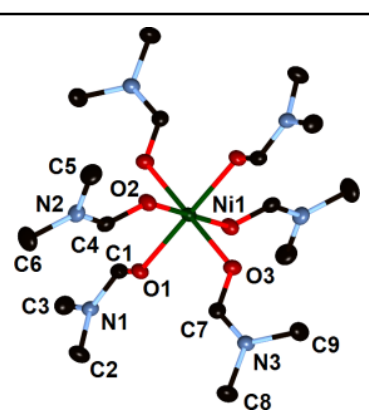

Fig. 6. X-ray structure of the cationic portion of 4+2DMF. Ellipsoids are at the $50 \%$ level and all hydrogen atoms and tosylate anions are removed for clarity.

Complex 4+2DMF crystallizes as a six coordinate complex in the monoclinic $P 2_{1} / n$ space group [Table 2]. The homoleptic $\left[\mathrm{Ni}^{\mathrm{II}}(\mathrm{DMF})_{6}\right]^{2+}$ cation has $\mathrm{Ni}-\mathrm{O}$ bonds that range from 2.042(2) to 2.062(1) $\AA$ [Ni1-O3 and Ni1-O2] and are in the typical range seen for six coordinate nickel complexes, being identical to those in $\left[\mathrm{NH}_{4}\right]_{2} \mathrm{Ni}^{\mathrm{II}}\left[\mathrm{SO}_{4}\right]_{2} \cdot 6 \mathrm{H}_{2} \mathrm{O}$ [avg. 2.04(3) $\AA$ ] $[82,106]$. The outer sphere tosylate anions exhibit nearly identical S1-O distances [ca. 1.452(2) Å] and slightly longer S1-C bonds in comparison to the other structures supporting the assumption that charge is efficiently delocalized over the $\mathrm{SO}_{3}{ }^{-}$fragment [Table 3]. The S-O bonds in 4+2DMF are only slightly shorter than those seen in Tutton's salt analogues [avg. 1.49(3) ̊]. The $\mathrm{O}-\mathrm{Ni1}-\mathrm{O}$ angles range between $89.43(5)$ and $92.86(5)^{\circ}$ and are comparable to those in $\left[\mathrm{NH}_{4}\right]_{2} \mathrm{Ni}^{\mathrm{II}}\left[\mathrm{SO}_{4}\right]_{2} \cdot 6 \mathrm{H}_{2} \mathrm{O} \quad[89.5(1)$ to $92.7(2)^{\circ}$, indicating 4+2DMF adopts a nearly ideal octahedral coordination geometry [82].

Magnetic measurements confirm the tosylate complexes are paramagnetic and contain divalent transition metal centers. Consistent with previously described spectroscopic data we find orbital contributions are nearly quenched for the octahedral complexes with each adopting effective magnetic moments that are close to the expected spin-only values [190]. The magnetic data indicate that $\mathrm{Cr}^{\mathrm{II}}{ }_{\mathrm{HS}}\left(S=2,5.02 \mu_{\mathrm{B}}\right), \mathrm{Fe}^{\mathrm{II}}{ }_{\mathrm{HS}}\left(S=2,4.82 \mu_{\mathrm{B}}\right)$, and $\mathrm{Co}_{\mathrm{HS}}^{\mathrm{II}}\left(S=3 / 2,3.87 \mu_{\mathrm{B}}\right)$ and $\mathrm{Ni}^{\mathrm{II}}\left(S=1,2.71 \mu_{\mathrm{B}}\right)$ spin centers 
are present in 1-4, respectively, where $\mu_{\mathrm{B}}$ is the Bohr magneton [190,214]. These data are consistent with charge balance considerations and confirm the validity of previously described spectroscopic and structural data.

\section{Conclusions}

A series of solvated divalent $p$-toluenesulfonate complexes and chains may be readily prepared and isolated as crystalline materials. The complexes are highly soluble in polar organic media and easily afford desolvated materials in the presence of non- or weakly-coordinating solvents. The spectroscopic properties of dissolved tosylates are similar to mononuclear octahedral aqua complexes indicating that the anions are outer sphere in solution. Magnetic studies confirm the isolated materials contain divalent metal ions with high spin states favoured for the chromium, manganese, iron, and cobalt complexes.

\section{Acknowledgements}

S.M.H. gratefully acknowledges the National Science Foundation (CHE-0939987, X-ray upgrade; CHE-1214063) for financial support. High school student training programs Students and Teachers as Research Scientists (STARS; J.E. and T.E.) and American Chemical Society SEED (H.N.) are also thanked for partial support of this research.

\section{References}

[1] S.H. Strauss, Chem. Rev. 93 (1993) 927;

[2] D.H. Geske, J. Phys. Chem. 63 (1959) 1062;

[3] M.G. Hill, W.M. Lamanna, K.R. Mann, Inorg. Chem. 30 (1991) 4687;

[4] G.A. Lawrance, Chem. Rev. 86 (1986) 17;

[5] S.M. Holmes, S.G. McKinley, G.S. Girolami, Inorg. Synth. 33 (2002) 91;

[6] S.M. Holmes, thesis, Molecule-Based Magnets Constructed from Hexacyanometalates, University of Illinois at Urbana-Champaign, Urbana, 1999;

[7] T.R. Musgrave, T.S. Lin, J. Coord. Chem. 2 (1973) 323;

[8] R.A. Heintz, J.A. Smith, P.S. Szalay, A. Weisgerber, K.R. Dunbar, Inorg. Synth. 33 (2002) 75;

[9] W.E. Buschmann, J.S. Miller, Inorg. Synth. 33 (2002) 83;

[10] N.E. Dixon, G.A. Lawrance, P.A. Lay, A.M. Sargeson, H. Taube, Inorg. Synth. 24 (1986) 342;

[11] J.B. Hendrickson, D.D. Stembach, K.W. Baur, Acc. Chem. Res. 10 (1977) 306;

[12] R.D. Howells, J.D. McCown, Chem. Rev. 71 (1977) 67;

[13] A. Scott, H. Taube, Inorg. Chem. 10 (1971) 62;

[14] R. Roth, Zur Kenntnis der Perchlorate, Munich, 1910, and references cited therein; W.G. Wyckoff, Crystal Structures, $2^{\text {nd }}$ Ed., vol. 3, Interscience, New York, 1960, and references cited therein;

[15] J.C. Schumacher, Perchlorates. Their Properties, Manufacture and Uses. Reinhold Publ. Corp., New York, 1960, and references cited therein;

[16] J.W. Mellor, A Comprehensive Treatise on Inorganic and Theoretical Chemistry, V. 2, Longmans, Green, and Co., London, 1922, and references cited therein;

[17] G.S. Sérullas, Ann Chim. Phys. 46 (1831) 257;

[18] A. Polititzin, J. Russ. Phys. Chem. 19 (1887) 339;

[19] J.W. Retgers, Z. Phys. Chem. 8 (1891) 19;

[20] F. Penney, Liebig's Ann. 37 (1841) 297;

[21] T. Schlössing, Compt. Rend. 73 (1871) 1271;

[22] G.S. Sérullas, Ann Chim. Phys. 46 (1831) 257;

[23] J. von Liebig, Mag. Pharm. 34 (1831) 128;

[24] J.C.G. de Marignac, Bibl. Univ. 45 (1843) 346;

[25] K.G. Roth, Pogg. Ann. 133 (1868) 213;

[26] G.S. Sérullas, Ann Chim. Phys. 46 (1831) 306;

[27] P. Groth, Pogg. Ann. 133 (1868) 226;

[28] A. Atterberg, Ber. 7 (1873) 472;

[29] A. Atterberg, Bull. Soc. Chim. 24 (1875) 358;

[30] J.C.G de Marignac, Ann. Chim. Phys. 46 (1831) 304;
[31] M.M.P. Muir, Chem. News 33 (1876) 15;

[32] G.S. Sérullas, Ann Chim. Phys. 46 (1831) 304

[33] F.C. Mathers, C.G. Schlüderberg, J. Am. Chem. Soc. 30 (1908) 211;

[34] W. Crookes, Chem. News 8 (1863) pp. 195, 219, 231, 243, 255, 279;

[35] J.W. Retgers, Z. Phys. Chem. 8 (1891) 17;

[36] H.E. Roscoe, Leibig's Ann. 121 (1862) 355;

[37] W. Crookes, Phil. Trans. 15A (1908) 209;

[38] C.D. West, Z. Krist, 91A (1935), 480;

[39] N.V. Sidgwick, The Chemical Elements and Their Compounds, VII, Oxford, 1950;

[40] F. Hein, S. Herzog, Handbook of Preparative Inorganic Chemistry, $2^{\text {nd }}$ Ed., 1965, pp. 1361-1370, Academic, NY;

[41] D.G. Holah, J.P. Fackler, 10 (1967) 26;

[42] F. Sobot, Bull. Soc. Min. 34 (1911) 144;

[43] J. P. Fackler, D.G. Holah, Inorg. Chem. 4 (1965) 954;

[44] S.A. Shchukarev, S.N. Andreev, T.G. Balicheva, L.N. Nechaeva, Ser. Fiz. I Khim. 3 (1961) 120;

[45] G. Monnier, Ann. Chim (Paris) 2 (1957) 14;

[46] C.F. Wells, G. Davies, J. Chem. Soc. A (1967) 1858;

[47] H.E. Roscoe, Liebig's Ann. 121 (1862) 355;

[48] H.L. Schlafer, W. Schaffernicht, Angew. Chem. 72 (1960) 818;

[49] G. Bødtker-Naess, O. Hassel, Norke Videnskaps-Akad. Oslo I. Mat. Naturv. Kl., No. 4 and 7;

[50] G. Bødtker-Naess, O. Hassel, Z. Anorg. Allgem. Chem. 211 (1933) 21;

[51] G. Bødtker-Naess, O. Hassel,Z. Physik. Chem. 22B (1933) 1089;

[52] C.D. West, Z. Krist. 91A (1935) 181;

[53] P. Groth, Pogg. Ann. 133 (1868) 213;

[54] P. Groth, F. Terlikowsky, R. Roth, L'étude de préparation et des propirétés de quelques perchlorates, Geneva, 1911;

[55] P.T. Cleve, Bull. Soc. Chim. 21 (1874) 156;

[56] P.T. Cleve, Bull. Soc. Chim. 23 (1876) 344;

[57] F.P.V. Venable, I.W. Smithey, J. Soc. Chem. Ind. 41 (1919) 1722;

[58] P. Groth, Pogg. Ann. 133 (1868) 226;

[59] H.E. Roscoe, Proc. Roy. Soc. 11 (1862) 502;

[60] H.E. Roscoe, Liebig's Ann. 121 (1862) 356;

[61] G.S. Sérullas, Ann. Chim. Phys. 45 (1831) 2;

[62] H.E. Roscoe, J. Chem. Soc. 19 (1866) 504;

[63] P.T. Cleve, Bull. Soc. Chim. 29 (1878) 492;

[64] S. Jolin, Bull. Soc. Chim. 21 (1874) 533;

[65] G.T. Morgan, E. Cahen, J. Chem. Soc. 91 (1907) 91;

[66] P.T. Cleve Bull. Soc. Chim. 21 (1874) 116;

[67] R. Alexander, E.C.F. Ko, Y.C. Mac, A.J. Parker, J. Am. Chem. Soc. 89 (1967) 3703;

[68] IUPAC Solubility Data Series, 41, Alkaline Earth Metal Perchlorates, Pergamon Press, New York, 1989.

[69] J.C. Schumacher, Perchlorates. Their Properties, Manufacture and Uses., Reinhold Publ. Corp., New York, 1960, and references cited therein;

[70] R. Longhi, R.S. Drago, Inorg. Chem. 4 (1965) 11;

[71] U. Alvisi, Gazz. Chim. Ital. 31 (1901) 289;

[72] O. Hassel, H. Kringstad, Z. Anorg. Allgem. Chem. 209 (1932) 281;

[73] J.J. Habeeb, F.F. Said, D.G. Tuck, J. Chem. Soc., Dalton Trans. (1981) 118 ;

[74] E. Kamieńska, I. Uruska, Bull. Acad. Pol Sci. Ser. Sci. Chim. 21 (1973) 587 ;

[75] W.L. Groeneveld, J.J. van Houte, A.P. Zaur, Pecl. Trav. Chim. Pays-Bas, 755 (1968);

[76] D.G.L. Holt, L.F. Larkworthy, D.C. Povey, G.W. Smith, G.J. Leigh, Inorg. Chim. Acta 169 (1990) 201;

[77] R.W. Cockman, B.F. Hoskins, M.J. McCormick, T.A. O’Donnell, Inorg. Chem. 27 (1988) 2742;

[78] N.E. Dixon, G.A. Lawrance, P.A. Lay, A.M. Sargeson, H. Taube, Inorg. Synth. 24 (1986) 259;

[79] E. Kamieńska, I. Uruska, Electrochim. Acta 22 (1977) 181;

[80] F.A. Cotton, L.M. Daniels, C.A. Murillo, Inorg. Chem. 32 (1993) 4868;

[81] F.A. Cotton, L.R. Falvello, C.A. Murillo, J.F. Quesada, J. Solid State Chem. 96 (1992) 192;

[82] F.A. Cotton, L.R. Falvello, C.A. Murillo, J.F. Quesada, Inorg. Chem. 32 (1992) 4861;

[83] O. Hassel, J.R. Salvesen, Z. Physik. Chem. 126 (1927) 345;

[84] W.C. Hamilton, Acta Crystallogr. 15 (1962) 353;

[85] D.J. Sutor, Acta Crystallogr. 12 (1959) 72;

[86] M.B. Hossain, D. van der Helm, Inorg. Chem. 17 (1978) 2893

[87] R.R. Schrock, J.A. Osborn, Inorg. Chem. 9 (1970) 2339;

[88] M.J. Nolte, G. Gafner, Acta Crystallogr. B30 (1974) 738;

[89] P. Albano, M. Aressa, M. Manassero, Inorg. Chem. 19 (1980) 1069;

[90] S.J. Anderson, F.J. Wells, G. Wilkinson, B. Hussain, M.B. Hursthouse, Polyhedron 7 (1988) 2615;

[91] V.H. Hartmann, H.L.Z. Schlafer, Naturforschg 6A (1951) 754; 
[92] A. Earnshaw, L.F. Larkworthy, K.C. Patel, J. Chem. Soc. A (1969) 1339;

[93] M. Géloso, J. Faheme, Nouveau Traité de Chemie Minérale, P. Pascal, Ed., Musson el Cie, VIS (1960) 963;

[94] J.P. Fackler, D.G. Holah, Inorg. Chem. 4 (1965) 954;

[95] W.H. Baur, Acta Crystallogr. 8 (1962) 815;

[96] B.N. Figgis, J. Lewis, Prog. Inorg. Chem. 6 (1964) 37;

[97] C.A. Beevers, H. Lipson, Z. Krist. 82 (1932) 297;

[98] R.B. Corey, R.W.G. Wykoff, Z. Krist. 84 (1933) 477;

[99] C. Frondel, C. Palache, Am. Mineralogist 34 (1949) 188;

[100] D.J. Sutor, Acta Crystallogr. 12 (1959) 72;

[101] J.K. Beattie, S.P. Best, P. Del Favero, B.W. Skelton, A.N. Sobolev, A.H. White, J. Chem. Soc., Dalton Trans. (1996) 1481;

[102] L.F. Larkworthy, J.M. Murphy, K.C. Patel, D.J. Phillips, J. Chem Soc. A (1968) 2936;

[103] A.E.H. Tutton, Phil. Trans. 216 (1916) 1;

[104] R.G.W. Wychoff, Crystal Structures, $2^{\text {nd }}$. Ed., Interscience, 3 (1965);

[105] N.W. Grimes, H.F. Kay, M.W. Webb, Acta Crystallogr. 16 (1963) 823;

[106] B.N. Figgis, J. Lewis, Prog. Inorg. Chem. 6 (1964) 176;

[107] A. Earnshaw, L.F. Larkworthy, K.C. Patel, G. Beech, J. Chem. Soc. A (1969) 1334;

[108] W.F. Donovan, P.B. Smith, J. Chem. Soc., Dalton Trans. (1975) 894;

[109] K.G. Shields, C.H.L. Kennard, Cryst. Struct. Commun. 1 (1972) 189;

[110] J.J. van der Zee, K.G. Shields, A.J. Graham, C.H.L. Kennard, Cryst. Struct. Commun. 1 (1972) 367;

[111] K.G. Shields, J.J. van der Zee, C.H.L. Kennard, Cryst. Struct. Commun. 1 (1972) 371;

[112] G.H. Brown, R. Chidambaram, Acta Crystallogr. B25 (1969) 676;

[113] R.V. Chastain, J.J. Natt, A.M. Witkowska, E.C. Lingafelter, Acta Crystallogr. 22 (1967) 775

[114] J.K. Beattie, S.P. Best, P. Del Favero, B.W. Skelton, A.N. Sobolev, A.H. White, J. Chem. Soc., Dalton Trans. (1996) 1481;

[115] L.F. Larkworthy, J.M. Murphy, K.C. Patel, D.J. Phillips, J. Chem Soc. A (1968) 2936;

[116] R.C. Guha, Proc. Roy. Soc. 206A (1951) 353;

[117] T.J. Swift, Inorg. Chem. 3 (1964) 526;

[118] W. Schneider, Acta Crystallogr. 14 (1961) 784;

[119] K. Kohler, W. Frankee, Acta Crystallogr. 17 (1964) 1088;

[120] G. Gattow, J. Zeeman, Z. Anorg. Allgem. Chem. 293 (1958) 23;

[121] N.S. Hush, R.J.M. Hobbs, Prog. Inorg. Chem. 10 (1968) 259;

[122] T.S. Davis, J.P. Fackler, M.J. Weeks, Inorg. Chem. 7 (1968) 1994;

[123] J.N. Brazier, A.A. Woolf, J. Chem. Soc. A (1967) 99;

[124] R.C. Paul, S. Singh, R.C. Kumar, R.D. Sharma, R.D. Verma, Ind. J. Chem. 17A (1979) 273;

[125] R.C. Paul, N.C. Sharma; R.D. Verma, A.K. Sharma, Ind. J. Chem. 14A (1976) 705

[126] C.S. Alleyne, K. O'Sullivan Mailer, R.C. Thompson, Can. J. Chem. 52 (1974) 336;

[127] J.M. Taylor, R.C. Thompson, Can. J. Chem. 49 (1971) 511;

[128] R.D. Verma, R.C. Kumar, Ind. J. Chem. 15A (1977) 363;

[129] R.C. Paul, V.P. Kapila, S.K. Sharma, Ind. J. Chem. 12 (1974) 651;

[130] R.C. Paul, V.P. Kapila, N. Palta, S.K. Sharma, Ind. J. Chem. 12 (1974) 825 ;

[131] R. Feld, J. Chem. Soc. (1964) 3963;

[132] R.C. Paul, V.P. Kapila, S.K. Sharma, J. Inorg. Nucl. Chem. 36 (1974) 1933 ;

[133] S. Kumar, S.K. Gupta, S. K. Sharma, Thermochim. Acta 71 (1983) 193;

[134] A.L. Arduini, M. Garnett, R.C. Thompson, T.C.T. Wong, Can. J. Chem. 53 (1975) 3812;

[135] J.S. Haynes, J.R. Sams, R.C. Thompson, Can. J. Chem. 59 (1981) 669;

[136] D.A. Buckingham, P.J. Cresswell, W.G. Jackson, A.M. Sargeson, Inorg. Chem. 20 (1981) 1647;

[137] W.C. Kupferschmidt, R.B. Jordan, Inorg. Chem. 21 (1982) 2089;

[138] K. Bourmizane, M.H. Herzog-Cance, D.J. Jones, J.L. Pascal, J. Potier, J. Roziere, Polyhedron 10 (1991) 2757;

[139] R.E. Noftle, G.H. Cady, Inorg. Chem. 12 (1966) 2182

[140] K. Boumizane, M.H. Herzog-Cance, D. Jones, J.L. Pascal, J. Potier, J. Roziere, Polyhedron 10 (1991) 2757;

[141] P.J. Riedel, N. Arulsamy, M.P. Mehn, Inorg. Chem. Commun. 14 (2011) 734;

[142] J.L. Brumaghim, C.L. Gross, G.S. Girolami, J. Organomet. Chem. 691 (2006) 3874;

[143] J.-C. Berthet, M. Nierlich, M. Ephritikhine, Polyhedron 22 (2003) 3475;

[144] J.-C. Berthet, M. Nierlich, M. Ephritikhine, Chimie 5 (2002) 81;

[145] J.-C. Berthet, M. Ephritikhine, Coord. Chem. Rev. 178-180 (1998) 83;

[146] R.J. Batchelor, J.N.R. Ruddick, J.R. Sams, F. Aubke, Inorg. Chem. 16 (1977) 1414;

[147] A. Abbasi, P. Lindqvist-Reis, L. Eriksson, D. Sandström, S. Lidin, I. Persson, M. Sandström, Chem. Eur. J. 11 (2005) 4065;
[148] N.E. Dixon, G.A. Lawrance, P.A. Lay, A.M. Sargeson, H. Taube, Inorg. Synth. 24 (1986) 250;

[149] T. Hayashida, H. Kondo, J.-i. Terasawa, K. Kirchner, Y. Sunada, H. Nagashima, J. Organomet. Chem. 692 (2007) 382;

[150] G.A. Lawrance, A.M. Sargeson, Inorg. Synth. 24 (1986) 263;

[151] P.A. Lay, R.H. Magnuson, J. Sen, H. Taube, J. Am. Chem. Soc. 104 (1982) 7658 ;

[152] P.A. Lay, Magnuson, R. H.; Taube, H. Inorg. Chem. 1989, 28, 30013007.

[153] N.E. Dixon, G.A. Lawrance, P.A. Lay, A.M. Sargeson, H. Taube, Inorg. Synth. 24 (1986) 269;

[154] B. Anderes, S.T. Collins, D.K. Lavallee, Inorg. Chem. 23 (1984) 2201;

[155] N.E. Dixon, W.G. Jackson, M.J. Lancaster, G.A. Lawrance, A.M. Sargeson, Inorg. Chem. 20 (1981) 470;

[156] N.E. Dixon, W.G. Jackson, W. G.; Lawrance, G. A.; Sargeson, A. M Inorg. Synth. 22 (1983) 103;

[157] N.E. Dixon, W.G. Jackson, G.A. Lawrance, A.M. Sargeson, Inorg. Synth 22 (1983) 105;

[158] N.E. Dixon, G.A. Lawrance, P.A. Lay, A.M. Sargeson, Inorg. Chem. 22 (1983) 847 ;

[159] G.A. Lawrance, A.M. Sargeson, Inorg. Synth. 24 (1986) 279;

[160] P.A. Lay, A.M. Sargeson, Inorg. Synth. 24 (1986) 283;

[161] P.A. Lay, A.M. Sargeson, H. Taube, Inorg. Synth. 24 (1986) 287;

[162] P.A. Lay, A.M. Sargeson, H. Taube, Inorg. Synth. 24 (1986) 291;

[163] D.C. Ware, P.A. Lay, H. Taube, Inorg. Synth. 24 (1986) 299;

[164] C. Diver, G.A. Lawrance, J. Chem. Soc., Dalton Trans. (1988) 931;

[165] N.J. Curtis, G.A. Lawrance, A.M. Sargeson, Inorg. Synth. 24 (1986) 277;

[166] M. Bombín, M.A. Martinez-Zaporta, A. Ramirez, A. Guerro, A.J. Mendez, Thermochim. Acta 224 (1993) 151;

[167] E.J. Kosnic, E.L. McClymont, R.A. Hodder, P.J. Sqattrito, Inorg. Chim Acta 244 (1996) 253;

[168] M.A. Leonard, P.J. Squattrito, S.N. Dubey, Acta Crystallogr. C55 (1999) 35 ;

[169] Y. Ohki, Y. Suzuki, T. Takeuchi, A. Ouchi, Bull. Chem. Soc. Jpn. 61 (1988) 393;

[170] C. Couldwell, K. Prout, D. Bobey, R. Taylor, F.J.C. Rossotti, Acta Crystallogr. B34 (1978) 1491;

[171] A. Guerrero-Laverat, A. Ramírez, A. Jerónimo, A. Santos, F. Florencio, S. Martínez-Carrera, S. García-Blanco, Inorg. Chim. Acta 128 (1987) 113

[172] M.A.S. Aquino, W. Clegg, Q. Liu, A.G. Sykes, Acta Crystallogr. C51 (1995) 560;

[173] K.O. Debevc, C. Pohar, V. Vlachy, J. Soln. Chem. 25 (1996) 787;

[174] B. Sun, Y. Zhao, J.-G. Wu, Q.-C. Yang, G.-X. Xu, J. Molec. Struct. 470 (1998) 63;

[175] S. Cabaleiro-Martinez, J. Castro, J. Romero, J.A. Garcia-Vazquez, A. Sousa, Acta Crystallogr. C56 (2000) e249;

[176] J.S. Haynes, J.R. Sams, R.C. Thompson, Can. J. Chem. 59 (1981) 669;

[177] A.S. Batsanov, J.A.K. Howard, N.S. Moore, M. Kilner, Acta Crystallogr. E57 (2001) m485

[178] V.P. Kapila, B. Kapila, S. Kumar, Ind. J. Chem. 30A (1991) 908;

[179] P. Bernhard, H.-B. Bürgi, J. Hauser, H. Lehmann, A. Ludi, Inorg. Chem. 21 (1982) 3936;

[180] W. Luginbühl, A. Ludi, A. Raselli, H. Bürgi, Acta Crystallogr. C45 (1989) 1428 ;

[181] P. Kapoor, P. Wadhawan, S. Tuli, Ind. J. Chem. 29A (1990) 982;

[182] E.J. Kosnic, E.L. McClymont, R.A. Hodder, P.J. Squattrito, Inorg. Chim. Acta 244 (1996) 253;

[183] E.J. Kosnic, E.L. McClymont, R.A. Hodder, P.J. Squattrito, Inorg. Chim. Acta 201 (1992) 143;

[184] K.O. Debevc, C. Pohar, V. Vlachy, J. Soln. Chem. 25 (1996) 787;

[185] M.A.S. Aquino, W. Clegg, Q. Liu, A.G. Sykes, Acta Crystallogr. C51 (1995) 560;

[186] T. Fajinayaga, I. Sakamoto, Pure Appl. Chem. 52 (1980) 1389;

[187] W.G. Jackson, G.A. Lawrance, P.A. Lay, A.M. Sargeson, Aust. J. Chem. 35 (1982) 1561

[188] J. MacHarrowfield, A.M. Sargeson, B. Singh, J.C. Sullivan, Inorg. Chem. 14 (1975) 2864

[189] W.G. Jackson, C.M. Beghie, Inorg. Chem. 20 (1981) 1654;

[190] E.A. Boubreaux, L.N. Mulay, Theory and Applications of Molecular Paramagnetism, Wiley, 1962;

[191] Z. Otwinowski, W. Minor, Methods Enzymol. 276 (1997) 307;

[192] G.M. Sheldrick, SHELX-97. Programs for Crystal Structure Solution and Refinement; University of Göttingen, Göttingen, Germany, 1997;

[193] G.M. Sheldrick, SADABS- An empirical absorption correction program; Bruker Analytical X-ray Systems, Madison, Wisconsin, 1996;

[194] G.M. Sheldrick, Acta Cryst. C71 (2015) 3; 
[195] International Tables for Crystallography Vol. C, Kluwer Academic Publishers, Dordrecht, The Netherlands, 1992;

[196] D.-F. Li, R. Clérac, S. Parkin, G.-B. Wang, G.T. Yee, S.M. Holmes, Inorg. Chem. 45 (2006) 5251.

[197] A.A. Maryott, E.R. Smith Table of Dielectric Constants of Pure Liquids, National Bureau of Standards Circular 514, 1951;

[198] K. Nakamoto, Infrared and Raman Spectra of Inorganic and Coordination Compounds, Part B, 5th Ed., John Wiley \& Sons, New York, 1997;

[199] Y. Tanabe, S. Sugano, J. Phys. Soc. Jpn. 9 (1954) 766;

[200] A.B.P. Lever, Inorganic Electronic Spectroscopy, VCH, New York, 1994;

[201] C.K. Jørgenson, Absorption Spectra and Chemical Bonding in Complexes, Pergamon Press, New York, 1964;

[202] A.B.P. Lever, J. Chem. Educ. 45 (1968) 711;

[203] R.S. Drago, Physical Methods for Chemists, 2nd Ed., Saunders College Publishers, New York, 1992, pp. 735-736.

[204] E.I. Solomon, A.B.P. Lever, Inorganic Electronic Structure and Spectroscopy, vols. I and II, Wiley, New York, 2006;

[205] D.W. Meeks, R.S. Drago, T.S. Piper, Inorg. Chem. 1 (1962) 285;

[206] D.M. Meek, R.S. Drago, T.S. Piper, Inorg. Chem. 1 (1962) 285;

[207] C.K. Jørgenson, Acta Chem. Scand. 9 (1955) 1362;

[208] D.W. Meeks, R.S. Drago, T.S. Piper, Inorg. Chem. 1 (1962) 285;

[209] V. Imhof, R.S. Drago, Inorg. Chem. 4 (1965) 427;

[210] O. Bostrup, C.K. Jørgenson, Acta Chem. Scand. 11 (1957) 1223;

[211] A. Bose, R. Chatterjee, Proc. Phys. Soc. 83 (1963) 23;

[212] E. Konig, Struct. Bond. 9 (1971) 175;

[213] F. Charbonnier, R. Fauer, H. Loiseleur, Acta Crystallogr. 34B (1978) 1504;

[214] P.J. Ferko, J.R. Withers, H. Nguyen, J. Ema, T. Ema, C. Dornhoefer, N.P. Rath, S.M. Holmes, J. Chem. Educ., in press;

[215] J.Y. Jeon, J.H. Park, D.S. Park, S.Y. Park, C.S. Lee, M.J. Go, J. Lee, B.Y. Lee, Inorg. Chem. Commun. 44 (2014) 148;

[216] C. Zitzer, T.W.T. Muesmann, J. Christoffers, M.S. Wickleder, New J. Chem. 39 (2015) 6117;

[217] A. Guerrero-Laverat, A. Ramírez, A. Jerónimo, A. Santos, F. Florencio, S. Martínez-Carrera, S. Garcia-Blanco, Inorg. Chim. Acta 128 (1987) 113 ; 
Table 1. Relative solubilities of $\left\{\right.$ trans $\left.-\left[\mathrm{Co}(\mathrm{OTs})_{2}(\mathrm{DMF})_{4}\right]\right\} \cdot \mathrm{H}_{2} \mathrm{O}(\mathbf{3})$ and $\left[\mathrm{Ni}(\mathrm{DMF})_{4}\right][\mathrm{OTs}]_{2}(\mathbf{4})$ in various organic solvents $(\varepsilon=$ dielectric constant).

\begin{tabular}{|c|c|c|c|c|c|c|c|c|c|c|}
\hline cmpd & $\begin{array}{c}\text { benzene } \\
(2.3)\end{array}$ & $\begin{array}{c}\text { diethyl ether } \\
(4.3)\end{array}$ & $\begin{array}{c}\text { chloroform } \\
(4.8)\end{array}$ & $\begin{array}{c}\text { tetrahydrofuran } \\
(7.5)\end{array}$ & $\begin{array}{c}\text { ethyl acetate } \\
(6.0)\end{array}$ & $\begin{array}{c}\text { dichloromethane } \\
(9.1)\end{array}$ & $\begin{array}{c}\text { pyridine } \\
(12.3)\end{array}$ & $\begin{array}{c}\text { tert-butyl alcohol } \\
(12.5)\end{array}$ & $\begin{array}{c}\text { 1,2-diaminoethane } \\
(14.2)\end{array}$ & $\begin{array}{c}\text { 2-propanol } \\
(18.3)\end{array}$ \\
\hline 3 & $\bullet$ & a & $\bullet$ & 0 & 0 & $\bullet$ & ! & a & ! & $\bullet$ \\
\hline 4 & n & - & $\bullet$ & $\circ$ & 0 & $\bullet$ & ! & a & a & $\bullet$ \\
\hline & $\begin{array}{c}\text { 1-propanol } \\
(20.1)\end{array}$ & $\begin{array}{l}\text { acetone } \\
(20.7)\end{array}$ & $\begin{array}{l}\text { ethanol } \\
(24.6)\end{array}$ & $\begin{array}{c}\text { 2,4-pentanedione } \\
(25.7)\end{array}$ & $\begin{array}{c}\text { methanol } \\
(32.6)\end{array}$ & $\begin{array}{c}\text { nitromethane } \\
(35.8)\end{array}$ & $\begin{array}{c}\text { acetonitrile } \\
(37.5)\end{array}$ & $\begin{array}{c}\text { dimethylfomamide } \\
(38.3)\end{array}$ & $\begin{array}{c}\text { dimethylsulfoxide } \\
(47)\end{array}$ & $\begin{array}{l}\text { water } \\
(78.5)\end{array}$ \\
\hline 3 & $\bullet$ & $\bullet$ & $\circ$ & 0 & ! & $\bullet$ & $\circ$ & a & $\circ$ & ! \\
\hline 4 & $\bullet$ & $\bullet$ & 0 & 0 & 口 & $\bullet$ & $\bullet$ & ! & 0 & - \\
\hline
\end{tabular}


Table 2. Crystallographic data for $\left\{\text { trans }-\mathrm{Cr}(\mathrm{OTs})_{2}(\mathrm{DMF})_{2}\right\}_{n}\left(\mathbf{1}-\mathrm{H}_{2} \mathrm{O}\right)$, trans $-\left[\mathrm{Fe}(\mathrm{OTs})_{2}(\mathrm{DMF})_{4}\right]\left(\mathbf{2}-\mathrm{H}_{2} \mathrm{O}\right)$, trans $-\left[\mathrm{Co}(\mathrm{OTs})_{2}(\mathrm{DMF})_{4}\right](\mathbf{3}),\left[\mathrm{Ni}(\mathrm{DMF})_{6}\right][\mathrm{OTs}]_{2}$ $(\mathbf{4}+2 \mathrm{DMF})$, and trans-[Fe(OTs) $\left.)_{2}(\mathrm{DMF})_{2}\left(\mathrm{OH}_{2}\right)_{2}\right](\mathbf{5})$.

\begin{tabular}{|c|c|c|c|c|c|}
\hline & 1 & 2 & $\mathbf{3}$ & 4 & 5 \\
\hline$\lambda, \AA$ & 0.71073 & 0.71073 & 0.71073 & 0.71073 & 0.71073 \\
\hline temp., $\mathrm{K}$ & $90.0(2)$ & $100(2)$ & $90.0(2)$ & $100(2)$ & $100(2)$ \\
\hline space group & $P 2_{1} / n$ & $P 2_{1} / n$ & $P 2_{1} / n$ & $P 2_{1} / n$ & $P-1$ \\
\hline$a, \AA$ & $14.5952(5)$ & 7.8561(7) & $7.8465(1)$ & $9.5355(7)$ & $6.3485(1)$ \\
\hline$b, \AA$ & $5.2241(2)$ & $24.663(2)$ & $24.5324(3)$ & $22.696(1)$ & $8.6866(2)$ \\
\hline$\beta,^{\circ}$ & $112.454(2)$ & $111.155(3)$ & $110.926(6)$ & 94.884(4) & $84.329(1)$ \\
\hline$\gamma,{ }^{\circ}$ & & & & & $76.869(1)$ \\
\hline$V, \AA^{3}$ & $1199.44(8)$ & $1595.4(2)$ & $1581.76(3)$ & $2024.5(2)$ & $647.57(2)$ \\
\hline $\bar{Z}$ & 2 & 2 & 2 & 2 & 1 \\
\hline$\rho_{\mathrm{c}}, \mathrm{g} \mathrm{cm}^{-3}$ & 1.497 & 1.438 & 1.456 & 1.377 & 1.488 \\
\hline$\mu, \mathrm{mm}^{-1}$ & 0.699 & 0.662 & 0.734 & 0.647 & 0.798 \\
\hline
\end{tabular}

${ }^{\mathrm{a}]} I \geq 2 \sigma(I) \cdot{ }^{[\mathrm{b}]} R_{1}=\sum|| \mathrm{F}_{\mathrm{o}}|-| \mathrm{F}_{\mathrm{c}}\left|/ \sum\right| \mathrm{F}_{\mathrm{o}} \mid{ }^{[\mathrm{cc}]} w R_{2}=\left\{\sum\left[w\left(\mathrm{~F}_{\mathrm{o}}{ }^{2}-\mathrm{F}_{\mathrm{c}}{ }^{2}\right)^{2}\right] / \sum\left[\mathrm{w}\left(\mathrm{F}_{\mathrm{o}}{ }^{2}\right)^{2}\right]\right\}^{1 / 2}$ 
Table 3. Selected Bond Distances $(\AA)$ and Angles $\left(^{\circ}\right)$ for $\left.\{\text { trans-Cr(OTs })_{2}(\mathrm{DMF})_{2}\right\}_{n}\left(\mathbf{1}-\mathrm{H}_{2} \mathrm{O}\right)$, trans-[Fe $\left.(\mathrm{OTs})_{2}(\mathrm{DMF})_{4}\right]\left(\mathbf{2}-\mathrm{H}_{2} \mathrm{O}\right)$, trans-[Co(OTs $\left.)_{2}(\mathrm{DMF})_{4}\right](\mathbf{3})$, $\left[\mathrm{Ni}(\mathrm{DMF})_{6}\right]-$ $[\mathrm{OTs}]_{2}(\mathbf{4}+2 \mathrm{DMF})$, and trans $-\left[\mathrm{Fe}(\mathrm{OTs})_{2}(\mathrm{DMF})_{2}\left(\mathrm{OH}_{2}\right)_{2}\right](\mathbf{5})$.

\begin{tabular}{|c|c|c|c|c|c|c|c|c|c|}
\hline 1 & & 2 & & $\mathbf{3}$ & & 4 & & 5 & \\
\hline Cr1-O2A & $2.076(2)$ & Fe1-O1 & $2.1237(7)$ & Co1-O1 & $2.028(1)$ & Ni1-O1 & $2.051(1)$ & Fe1-O1 & $2.1498(9)$ \\
\hline Cr1-O3 & $2.403(2)$ & $\mathrm{Fe} 1-\mathrm{O} 2$ & $2.1574(7)$ & Co1-O1A & $2.231(2)$ & Ni1-O2 & $2.062(1)$ & $\mathrm{Fe} 1-\mathrm{O} 2$ & $2.0804(7)$ \\
\hline Cr1-O4 & $2.038(2)$ & $\mathrm{Fe} 1-\mathrm{O} 3$ & $2.0958(7)$ & Co1-O1B & $2.049(1)$ & Ni1-O3 & $2.042(2)$ & Fe1-O3 & $2.1428(8)$ \\
\hline S1-O1 & $1.444(2)$ & S1-O3 & $1.4793(8)$ & S1-O1 & $1.490(2)$ & $\mathrm{O} 1-\mathrm{C} 1$ & $1.248(2)$ & S1-O3 & $1.4720(9)$ \\
\hline $\mathrm{S} 1-\mathrm{O} 2$ & $1.482(2)$ & S1-O4 & $1.4466(8)$ & S1-O2 & $1.367(2)$ & C1-N1 & $1.317(2)$ & S1-O4 & $1.4578(9)$ \\
\hline S1-O3 & $1.444(2)$ & S1-O5 & $1.4532(8)$ & S1-O3 & $1.579(2)$ & S1-O4 & $1.453(2)$ & S1-O5 & $1.4530(9)$ \\
\hline S1-C5 & $1.773(3)$ & S1-C7 & $1.774(1)$ & S1-C1 & $1.743(2)$ & S1-O5 & $1.456(2)$ & S1-C1 & $1.767(1)$ \\
\hline O4-C8 & $1.253(4)$ & O1-C1 & $1.243(1)$ & O1A-C1A & $1.305(3)$ & S1-06 & $1.453(2)$ & O2-C8 & $1.246(1)$ \\
\hline C8-N1 & $1.318(4)$ & C1-N1 & $1.327(1)$ & C1A-N1A & $1.435(3)$ & S1-C10 & $1.778(2)$ & C8-N1 & $1.323(1)$ \\
\hline 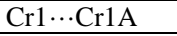 & $5.224(2)$ & $\mathrm{Fe} 1 \cdots \mathrm{Fe} 1 \mathrm{~A}$ & $7.847(1)$ & 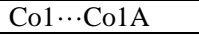 & $7.846(3)$ & Ni1 $\cdots$ Ni1A & $9.535(2)$ & $\mathrm{Fe} 1 \cdots \mathrm{Fe} 1 \mathrm{~A}$ & $6.348(1)$ \\
\hline 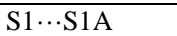 & $4.579(2)$ & S1 $\cdots$ S1A & $6.667(1)$ & S1 $\cdots$ S1A & $6.495(3)$ & 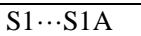 & $8.997(2)$ & S1 $\cdots$ S1A & $6.686(1)$ \\
\hline O4-Cr1-O2A & $89.85(8)$ & O1-Fe1-O2 & $88.34(3)$ & O1-Co1-O1A & $83.74(6)$ & O1-Ni1-O2 & $92.86(5)$ & O1-Fe1-O2 & $93.10(3)$ \\
\hline O3-Cr1-O2A & $87.00(1)$ & O1-Fe1-O3 & $89.28(3)$ & O1-Co1-O1B & $87.56(6)$ & O1-Ni1-O3 & $90.90(5)$ & O1-Fe1-O3 & $88.83(3)$ \\
\hline O1-S1-O2 & $110.3(1)$ & $\mathrm{O} 2-\mathrm{Fe} 1-\mathrm{O} 3$ & $90.42(3)$ & O1A-Co1-O1B & $92.44(6)$ & O2-Ni1-O3 & $89.43(5)$ & O2-Fe1-O3 & $93.18(3)$ \\
\hline O1-S1-O3 & $114.8(1)$ & O3-S1-O4 & $113.23(5)$ & O1-S1-O2 & 108.48(9) & O4-S1-O5 & $112.67(9)$ & O3-S1-O4 & $111.52(5)$ \\
\hline O1-S1-C5 & $106.5(1)$ & O3-S1-O5 & $110.32(5)$ & O1-S1-O3 & 114.94(9) & O4-S1-O6 & $113.38(9)$ & O3-S1-O5 & 111.59(5) \\
\hline O2-S1-O3 & $112.8(1)$ & O4-S1-O5 & $114.73(5)$ & O2-S1-O3 & $116.5(1)$ & O5-S1-O6 & $113.20(9)$ & O4-S1-O5 & 113.79(5) \\
\hline O4-C8-N1 & 124.1(3) & O3-S1-C7 & 104.91(4) & O1-S1-C1 & 104.55(9) & O4-S1-C10 & $104.58(9)$ & O3-S1-C1 & 106.94(5) \\
\hline S1-O2-Cr1 & $133.6(1)$ & O1-C1-N1 & $123.80(9)$ & O1A-C1A-N1A & $129.6(2)$ & O1-C1-N1 & 124.4(2) & O2-C8-N1 & 123.1(1) \\
\hline Cr1-O3-S1 & 142.662 & Fe1-O3-S1 & $137.22(4)$ & Co1-O1-S1 & $134.19(9)$ & Ni1-O1-C1 & $123.7(2)$ & Fe1-O3-S1 & 134.45(5) \\
\hline Cr1-O2A-S1A & 133.616 & Fe1-O1-C1 & $122.67(6)$ & Co1-O1A-C1A & $131.0(2)$ & Ni1-O2-C4 & 123.1(2) & Fe1-O2-C8 & 132.58(7) \\
\hline & & Fe1-O2-C4 & $125.14(6)$ & Co1-O1B-C1B & 118.4(1) & Ni1-O3-C7 & $125.3(2)$ & & \\
\hline
\end{tabular}


TOC

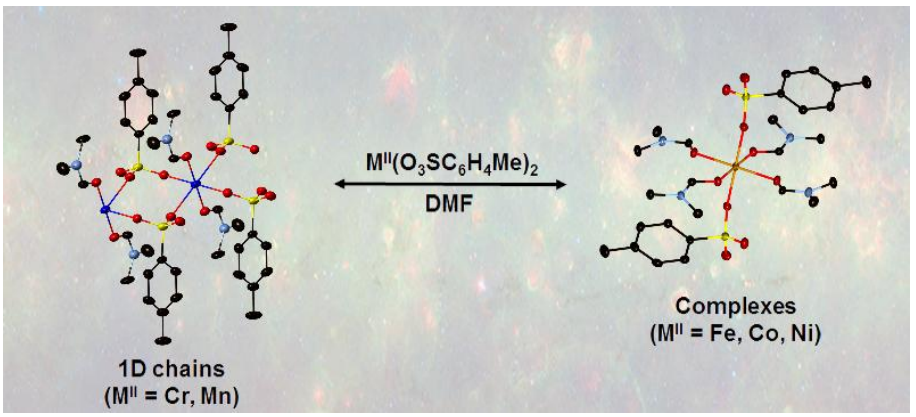

The structures, magnetism, and spectroscopic properties of several $3 d$ transition metal $p$-toluenesulfonate complexes and chains are described. A onedimensional chain $\left\{\text { trans }-\mathrm{Cr}^{\mathrm{I}}(\mathrm{DMF})_{2}(\mathrm{OTs})_{2}\right\}_{n} \cdot n \mathrm{H}_{2} \mathrm{O}$ (1) and mononuclear complexes of $\left\{\right.$ trans $\left.-\left[\mathrm{M}^{\mathrm{II}}(\mathrm{OTs})_{2}(\mathrm{DMF})_{4}\right]\right\} \cdot n \mathrm{H}_{2} \mathrm{O}\left(\mathrm{M}^{\mathrm{II}}=\mathrm{Fe}, \mathbf{2} ; \mathrm{Co}, \mathbf{3} ; n=1,0\right)$ and $\left[\mathrm{Ni}^{\mathrm{II}}(\mathrm{DMF})_{4}\right][\mathrm{OTs}]_{2}(\mathbf{4})$ stoichiometry are described. 